\title{
How will melting of ice affect volcanic hazards in the $21^{\text {st }}$ century?
}

\section{Hugh Tuffen}

Lancaster Environment Centre, Lancaster University, Lancaster LA1 4YQ, UK.

h.tuffen@lancaster.ac.uk

\section{Abstract}

1 Glaciers and ice sheets on many active volcanoes are rapidly receding. There is compelling evidence

2 that melting of ice during the last deglaciation triggered a dramatic acceleration in volcanic activity.

3 Will melting of ice this century, which is associated with climate change, similarly affect volcanic

4 activity and associated hazards?

5 This paper provides a critical overview of the evidence that current melting of ice will

6 increase the frequency or size of hazardous volcanic eruptions. Many aspects of the link between ice

7 recession and accelerated volcanic activity remain poorly understood. Key questions include how

8 rapidly volcanic systems react to melting of ice, whether volcanoes are sensitive to small changes in

9 ice thickness, and how recession of ice affects the generation, storage and eruption of magma at

10 stratovolcanoes. A greater frequency of collapse events at glaciated stratovolcanoes can be expected

11 in the near future, and there is strong potential for positive feedbacks between melting of ice and

12 enhanced volcanism. Nonetheless, much further research is required to remove current uncertainties

13 about the implications of climate change for volcanic hazards in the $21^{\text {st }}$ century.

\section{Key index words or phrases}

16 Volcanic hazards, climate change, volcano-ice interaction, ice sheets, glaciers, lahars 


\subsection{Introduction}

There is growing evidence that past changes in the thickness of ice covering volcanoes has affected their eruptive activity. Dating of Icelandic lavas has shown that the rate of volcanic activity in Iceland accelerated by a factor of 30-50 following the last deglaciation at $\sim 12 \mathrm{ka}$ (Maclennan et al. 2002). Analyses of local and global eruption databases have identified a statistically significant correlation between periods of climatic warming associated with recession of ice and an increase in the frequency of eruptions (Jellinek et al. 2004, Nowell et al. 2006, Huybers and Langmuir 2009). Today the bodies of ice found on many volcanoes are rapidly thinning and receding. These bodies range from extensive ice sheets to small tropical glaciers and thinning is thought to be triggered by contemporary climate change (e.g. Rivera et al. 2006, Vuille et al. 2008, Björnsson and Pálsson 2008).

This leads to the following question: will the current ice recession provoke increased volcanic activity and lead to increased exposure to volcanic hazards? In this paper I analyse our current knowledge of how ice thickness variations influence volcanism and identify several unresolved issues that currently prevent quantitative assessment of whether activity is likely to accelerate in the coming century. These include the poorly-constrained response time of volcanic systems to unloading of ice, uncertainty about how acceleration in volcanic activity scales to the rate and total amount of melting, and the lack of models to simulate how melting of ice on stratovolcanoes may affect magma storage and eruption to the surface. In conclusion I highlight some of the future research needed for better understanding of how melting of ice may force volcanic activity. 


\subsection{What are hazards at ice and snow-covered volcanoes and where are they found?}

Many volcanoes are mantled by ice and snow, especially those located at high latitudes or that reach over $4000 \mathrm{~m}$ in altitude. Notable examples occur in the Andes, the Cascades, the Aleutian-

Kamchatkan arc, Iceland, Antarctica, Japan and New Zealand (Fig. 1, Fig. 2). The nature of ice and snow cover spans a broad spectrum from seasonal snow (Mee et al. 2006), small bodies of ice and firn in summit regions (Houghton et al. 1987, Julio-Miranda et al. 2008), larger alpine glaciers on volcano flanks (Fig. 1b, Fig. 2a, e.g. Rivera et al. 2006, Vuille et al. 2008), thick ice accumulations within summit craters and calderas (e.g. Gilbert et al. 1996, Huggel et al. 2007a), to substantial ice sheets that completely cover volcanic systems (Fig. 2b, e.g. Guðmundsson et al. 1997, Corr and Vaughan 2008).

Historical eruptions at more than 40 volcanoes worldwide have involved disruption of ice and snow (Major and Newhall 1989), whereas numerous geological studies have enabled the recognition of interactions between volcanoes and ice or snow in ancient eruptions (e.g. NoeNygaard 1940, Mathews 1951, Gilbert et al. 1996, Smellie 1999, Lescinsky and Fink 2000, Mee et al. 2006). Volcanic deposits provide an invaluable record of palaeo-environmental change, such as

57 fluctuations in ice thickness and extent (Smellie et al. 2008, Smellie 2008, Tuffen et al. 2010), as well as the processes and hazards associated with various types of volcano-ice interaction (e.g.

59 Smellie and Skilling 1994, Smellie 1999, Lescinsky and Fink 2000, Tuffen and Castro 2009, 60 Carrivick 2007). 
64 The presence of ice and snow on volcanoes can greatly magnify hazards, principally because

65 perturbation of ice and snow during eruptions can rapidly generate large volumes of meltwater that

66 are released in destructive lahars and floods. Major and Newhall (1989) compiled a comprehensive

67 global review of historical eruptions at more than 40 volcanoes during which ice and snow were

68 perturbed and lahars or floods generated. Major loss of life occurred in several eruptions, including

69 Nevados de Ruiz (Columbia, 1985), Villarrica (Chile, 1971), Tokachi-dake (Japan, 1926) and

70 Cotopaxi (Ecuador, 1877).

72 Pertubation of ice and snow by volcanic activity. Major and Newhall identified five distinct

73 mechanisms that can cause perturbation of snow and ice or volcanoes: (1) mechanical erosion and

74 melting by flowing pyroclastic debris or blasts of hot gases (e.g. Walder 2000), (2) melting of the ice

75 or snow surface by lava flows (e.g. Mee et al. 2006), (3) basal melting by subglacial eruptions or

76 geothermal activity (e.g. Guðmundsson et al. 1997), (4) ejection of water by eruptions through a

77 crater lake, and (5) deposition of tephra onto ice and snow (e.g. Capra et al. 2004).

78 Subsequently, observations of volcanic activity in Columbia, Iceland, USA, New Zealand

79 and Alaska (Waitt 1989, Pierson et al., 1990, Guðmundsson et al. 1997, 2004, 2008; Carrivick et al.

$802009 a$ ) have highlighted how rapidly meltwater may be generated during melting of the base of ice

81 sheets and glaciers, and when pyroclastic debris move over ice and snow. Melting rates may exceed

$820.5 \mathrm{~km}^{3}$ per day during powerful subglacial eruptions (e.g. Guðmundsson et al. 2004). The hazards

83 associated with meltwater production are exacerbated when transient accumulation occurs with

84 craters or calderas, as this can lead to even higher release rates of meltwater when catastrophic 
85

drainage is triggered by dam collapse or floating of an ice barrier that allows rapid subglacial drainage (Pierson et al. 1990, Guðmundsson et al. 1997, Carrivick et al. 2004, 2009a).

The magnitude of meltwater floods (jökulhlaups and lahars) can exceed $40000 \mathrm{~m}^{3} \mathrm{~s}^{-1}$ (Major and Newhall 1989, Pierson et al. 1990, Guðmundsson et al. 2004, 2008), creating significant hazards in river valleys and on outwash plains many tens of kilometres from the site of melting (Fig. 1c,d; Fig. 2b; e.g. Pierson et al. 1990, Eliasson et al. 2006, Huggel et al. 2007a). The total volume of meltwater floods may be restricted by either the amount of pyroclastic material or lava available to cause melting, or the volume of ice and snow that can be melted.

Explosive eruptions. The hazards posed by explosive eruptions at ice- and snow-covered volcanoes are typical of those at other volcanoes, with the following important modifications: 1) Interactions between magma and meltwater may trigger phreatomagmatic activity (Fig. 1a), even during basaltic eruptions that would not otherwise be explosive (e.g. Smellie and Skilling 1994, Guðmundsson et al. 1997). 2) When ice is thick the explosive phase of eruptions may partly or entirely take place beneath the ice surface (Tuffen 2007), reducing the hazards associated with ashfall and pyroclastic debris. 3) If explosive eruptions do occur then widespread perturbation of ice and snow by pyroclastic material may be important, both at the vent area and in more distal areas.

Edifice instability and collapse. Ice-and snow-covered volcanic edifices are especially prone to collapse, creating hazardous debris avalanches that may convert to lahars (e.g. Huggel et al. $2007 a, b)$ and reach many tens of kilometres from their source. Collapse is favoured by 1) constraint by ice, which may encourage the development of structurally unstable, oversteepened edifices, 2) melting of ice, which may create weak zones at ice-bedrock interfaces (Huggel 2009) and 3) shallow 
108 hydrothermal alteration driven by snow and ice melt, which can greatly weaken volcanic edifices

109 (e.g. Carrasco-Núñez et al., 1993, Huggel 2009). Ice avalanches are a newly-recognised

110 phenomenon that may occur at ice-covered volcanoes (Fig. 2a; Huggel et al. 2007b). Ice avalanches

111 ranging from 0.1 to $20 \times 10^{6} \mathrm{~m}^{3}$ in volume originate from steep areas near the summit of Iliama

112 volcano, Alaska, where the geothermal flux is high. These avalanches travel up to $10 \mathrm{~km}$ down the

113 volcano flanks at speeds of 20-70 $\mathrm{m} \mathrm{s}^{-1}$ (Huggel 2009). The thermal perturbations that can trigger

114 slope failure include volcanic/geothermal, glacier-permafrost and climatically-induced warming.

115

116 The distribution of hazards at active ice and snow-covered volcanoes such as Citlaltepetl, Mexico

117 (lahars; Hubbard et al. 2007), Nevado de Ruiz, Columbia (lahars, avalanches; Huggel et al. 2007a),

118 Mt Rainier, Washington (lahars; Hoblitt et al. 1998), Ruapehu, New Zealand (lahars; Houghton et

119 al. 1987), Iliama, Alaska (lahars, avalanches; Waythomas and Miller 1999, Huggel et al. 2007b) and

120 Katla, Iceland (jökulhlaups, Björnsson et al. 2000) reflect these different sources of volcanic hazard,

121 principally meltwater floods, which potentially affect millions of people living close to these

122 volcanoes.

123

124 2. How is ice thickness on volcanoes currently changing?

125

126 Rapid thinning and recession of ice has been noted on many active and potentially-active volcanoes,

127 including Popocatepetl and other Mexican volcanoes (Julio-Miranda et al. 2008), Columbian

128 stratovolcanoes (Huggel et al. 2007a), Villarrica and other Chilean volcanoes (Rivera et al. 2006)

129 and Kilimanjaro, Tanzania (Fig. 3; Thompson et al. 2009). Ice sheets covering volcanic systems are

130 also rapidly thinning, including Vatnajökull in Iceland (Björnsson and Pálsson 2008) and parts of the 
131 West Antarctic Ice Sheet (Wingham et al. 2009). Selected measured or estimated rates of ice

132 thinning and recession are provided in Table 1.

133 Whereas the changing mass balance of thick ice sheets is predominantly manifested in a

134 reduction in ice surface elevation and therefore in ice thickness (e.g. Wingham et al. 2009), the

135 surface area of smaller glaciers on many volcanoes is rapidly reducing, along with a rapid decrease

136 in ice volume. Rates of thinning vary from $0.54 \mathrm{~m} \mathrm{a}^{-1}$ on Kilimanjaro (Thompson et al. 2009) to 1.6

$137 \mathrm{~m} \mathrm{a}^{-1}$ (Pine Island Glacier, West Antarctic Ice Sheet; Wingham et al. 2009). Assuming that current

138 rates of ice loss continue over the coming century, ice bodies on numerous volcanoes may therefore

139 thin by $\sim 50$ to 150 metres by 2100 . Stratovolcanoes hosting thin glaciers, such as Kilimanjaro, may

140 therefore become completely ice-free in the coming century (Thompson et al. 2009). At some

141 volcanoes this has already occurred, such as at Popocatepetl, Mexico where dramatic extinction of

142 summit ice over the last 50 years reached completion in 2004 (Julio-Miranda et al. 2008).

143

144

145

146

147

148

149

150

151 


\begin{tabular}{|c|c|c|c|c|}
\hline Volcano & $\begin{array}{l}\text { Last } \\
\text { eruption }\end{array}$ & $\begin{array}{l}\text { Area or volume } \\
\text { of ice }\end{array}$ & Rate of thinning & Reference \\
\hline $\begin{array}{l}\text { Vatnajökull, } \\
\text { Iceland }\end{array}$ & $\begin{array}{l}2004 \\
1998 \\
1996\end{array}$ & $\begin{array}{l}A=8100 \mathrm{~km}^{2} \\
V=3100 \mathrm{~km}^{3} \text { (in } \\
2000)\end{array}$ & $\begin{array}{l}0.8 \mathrm{~m} \mathrm{a}^{-1} \text { average (1995-2008) } \\
\text { Geothermal melting and eruptions } \\
\text { melted } 0.55 \mathrm{~km}^{3} \mathrm{a}^{-1}, \text { annual } \\
\text { surface ablation } 13 \mathrm{~km}^{3} \mathrm{a}^{-1} .\end{array}$ & $\begin{array}{l}\text { Pagli and } \\
\text { Sigmundsson } \\
\text { 2008, Björnsson } \\
\text { and Pálsson } 2008\end{array}$ \\
\hline $\begin{array}{l}\text { Volcán Villarrica, } \\
\text { Chile }\end{array}$ & $\begin{array}{l}2005 \\
2007 \\
2008\end{array}$ & $A=30.3 \mathrm{~km}^{2}$ & $0.81 \pm 0.45 \mathrm{~m} \mathrm{a}^{-1}(1961-2004)$ & Rivera et al. 2006 \\
\hline $\begin{array}{l}\text { Popocatepetl, } \\
\text { Mexico }\end{array}$ & $\begin{array}{l}1994- \\
2001\end{array}$ & $\begin{array}{l}\text { Was } 0.729 \mathrm{~km}^{2} \text { in } \\
1958, \text { now } 0 \mathrm{~km}^{2}\end{array}$ & $\begin{array}{l}1996 \sim 0.2 \mathrm{~m} \mathrm{a}^{-1} \\
1999 \sim 4 \mathrm{~m} \mathrm{a}^{-1}\end{array}$ & $\begin{array}{l}\text { Julio-Miranda et al } \\
2008\end{array}$ \\
\hline $\begin{array}{l}\text { Nevado del } \\
\text { Ruiz, Columbia }\end{array}$ & 1991 & $\begin{array}{l}A=19-25 \mathrm{~km}^{2} \\
(1985), 10.3 \mathrm{~km}^{2} \\
(2002-2003)\end{array}$ & Not known & $\begin{array}{l}\text { Ceballos et al. } \\
\text { 2006, Huggel et al. } \\
2007 \text { a }\end{array}$ \\
\hline $\begin{array}{l}\text { Cotopaxi, } \\
\text { Ecuador }\end{array}$ & 1940 & $\begin{array}{l}A=19.2 \mathrm{~km}^{2} \\
(1976), 13.4 \mathrm{~km}^{2} \\
(1997)\end{array}$ & $3-4 \mathrm{~m} \mathrm{a}^{-1}$ on snouts & Jordan et al. 2005 \\
\hline $\begin{array}{l}\text { Kilimanjaro, } \\
\text { Kenya/Tanzania }\end{array}$ & $\begin{array}{l}150-200 \\
\text { ka }\end{array}$ & $\begin{array}{l}A=2.5 \mathrm{~km}^{2} \\
(2000), 1.85 \mathrm{~km}^{2} \\
(2007)\end{array}$ & $0.54 \mathrm{~m} \mathrm{a}^{-1}$ & $\begin{array}{l}\text { Thompson et al. } \\
2009\end{array}$ \\
\hline $\begin{array}{l}\text { West Antarctic } \\
\text { lce Sheet }\end{array}$ & 2 ka? & $V=2.2 \times 10^{6} \mathrm{~km}^{3}$ & $\begin{array}{l}\text { Pine Island Glacier } \sim 1.6 \mathrm{~m} / \mathrm{a} \text {, } \\
\text { accelerating over } 1995-2006 .\end{array}$ & $\begin{array}{l}\text { Lythe and Vaughan } \\
2001 \text {, Shepherd et } \\
\text { al 2001, Corr and } \\
\text { Vaughan 2008, } \\
\text { Wingham et al } \\
2009 \text {. }\end{array}$ \\
\hline
\end{tabular}

153 Table 1. Current estimated rates of ice thinning and recession at selected volcanoes and ice sheets.

\subsection{Ice thinning due to climate change}

157 Much of the current recession and thinning of glaciers and ice sheets covering volcanoes is attributed

158 to the effects of global climate change, with increasing mean temperature and in some cases

159 decreasing precipitation leading to negative glacier mass balance changes (e.g. Rivera et al. 2006,

160 Bown and Rivera 2007, Vuille et al. 2008). The equilibrium line altitude (ELA) is the altitude on a

161 glacier where the annual accumulation and ablation rates are exactly balanced. The ELA of glaciers

162 on Chilean stratovolcanoes such as Villarrica has migrated upwards by 100 m between 1976 and

163 2004/2005 (Rivera et al. 2006), partly due to a mean temperature increase at 2000 m elevation of 
$1640.023{ }^{\circ} \mathrm{C} \mathrm{a}^{-1}$ (Bown and Rivera 2007). Ice thinning on Popocatepetl between 1958 and 1994 is

165 likewise thought to be related to climatic change (Julio-Miranda et al. 2008), as is dramatic thinning

166 of tropical mountain glaciers on Ecuadorian volcanoes such as Antizana and Cotopaxi (Vuille et al.

167 2008)

168 Thinning of Vatnajökull ice sheet in Iceland is also pronounced, with an average thinning of

$1690.8 \mathrm{~m} \mathrm{a}^{-1}$ between 1995 and 2008 (Björnsson and Pálsson 2008, Pagli and Sigmundsson 2008).

170 Future prediction of mass balance changes at Vatnajökull in the coming century, which incorporate

171 glacier dynamic models with predicted increases in mean temperature $\left(2.8^{\circ} \mathrm{C}\right)$ and precipitation $(6$

$172 \%$ ) project a $25 \%$ volume loss by 2060 (Björnsson and Pálsson 2008). The effects of climate change

173 on the mass balance of glaciers and ice sheets on volcanoes is likely to be strongly location-specific.

174 This is because changes in temperature and precipitation are spatially heterogeneous and glacier

175 dynamics highly variable. This local sensitivity is illustrated by the contrasting recession rates of

176 glaciers on neighbouring Chilean volcanoes less than $50 \mathrm{~km}$ apart (e.g. Rivera et al. 2006, Bown and

177 Rivera 2007) and highlights the importance of studying individual ice-covered volcanoes, rather than

178 applying a regional or global climate change model (Huybers and Langmuir 2009) to predict local

179 changes in ice thickness on specific volcanoes.

180

181 2.2. Ice thinning due to volcanic and geothermal activity

182 Volcanic and geothermal activity can strongly influence the mass balance of ice bodies on volcanoes

183 both during eruptions and periods of quiescence. The "background" ablation and accumulation rates

184 determine the overall effects of volcanic and geothermal activity on glacier mass balance and

185 dynamics (Magnusson et al. 2005, Guðmundsson et al. 2009). Mechanisms of ice loss include basal

186 melting and ice disruption during and after subglacial eruptive activity (Fig. 4a; e.g. Guðmundsson 
187 et al. 1997, Jarosch and Guðmundsson 2007), melting of the ice and snow surface by the heat of 188 erupted debris (Julio-Miranda et al. 2008), changes to surface albedo due to tephra cover (Fig. 4b;

189 Rivera et al. 2006), and lubrication by sustained basal melting due to geothermal heat (e.g. Bell

190 2008). Rapid melting, fracturing and mechanical erosion during eruptions can cause dramatic,

191 localised thinning of ice above vents (Fig. 4a) and meltwater drainage pathways (e.g. Guðmundsson

192 et al. 1997), with removal of tens or hundreds of metres of ice in hours. Perturbations to the ice

193 surface may be transient, however, as depressions formed may swiftly fill due to increased snow

194 deposition and inward deformation of surrounding ice (Aðalgeirsdóttir et al. 2000).

195 There is strong evidence that volcanic and geothermal activity is hastening the demise of ice

196 bodies on some volcanoes. Eruptive activity at Popocatepetl, Mexico from 1994 to 2001 led to the

197 complete extinction of its small $\left(<1 \mathrm{~km}^{2}\right)$ summit glaciers (Fig. 4b; Julio-Miranda et al. 2008). This

198 extinction reflects the negligible accumulation at a volcano located in an intertropical zone, which

199 makes its glacier mass balance extremely sensitive to eruption-triggered ablation. It is speculated

200 that the disappearance of ice on Popocatepetl was inevitable due to climate change, but greatly

201 hastened by eruptive activity (Julio-Miranda et al. 2008). Recent changes in the mass balance of

202 glaciers on Villarrica volcano, Chile reflect the effects of tephra cover on the ice surface (Rivera et

203 al. 2006). At Villarrica mass balance is also strongly influenced by basal geothermal fluxes. Tephra

204 cover drives enhanced melting when tephra is thin due to enhanced heat absorption, but thicker

205 layers may insulate ice and snow and reduce melting (Rivera et al. 2006, Brock et al. 2007).

206 Melting and mechanical removal of ice during the 1985 eruption of Nevado del Ruiz,

207 Columbia removed approximately $10 \%$ of the volume of ice on the volcano (Ceballos et al. 2006,

208 Huggel et al. 2007a), which totalled $0.48 \mathrm{~km}^{3}$ in 2003. This demonstrates that a single moderately

209 large volcanic eruption (VEI 3) can have an appreciable impact on the mass balance of ice on 
210 Andean stratovolcanoes, due to the low ice accumulation rates on tropical glaciers (Ceballos et al.

211 2006).

212 By contrast, even considerable volcanically-triggered melting probably has a negligible

213 effect on the mass balance of Iceland's Vatnajökull ice sheet over a decadal timescale. This is

214 because Icelandic glaciers and ice sheets are characterised by high annual accumulation and ablation

215 due to temperate conditions and extremely high precipitation (Björnsson and Pálsson 2008). At

216 Vatnajökull on average $0.55 \mathrm{~km}^{3} \mathrm{a}^{-1}$ was melted by volcanic eruptions during the period 1995-2008,

217 but this amounted to only $4 \%$ of the total surface ablation from the ice sheet during this period (13

$218 \mathrm{~km}^{3}$, Björnsson and Pálsson 2008). However, the effects of geothermal heat fluxes may have

219 significant effects on ice dynamics and mass balance over both long and short timescales: models of

220 the volume of Vatnajökull at the last glacial maximum are highly sensitive to basal geothermal heat

221 fluxes (Hubbard 2006) and eruption-triggered jökulhlaups may also trigger surging, which affects

222 glacier mass balance (Björnsson 1998, Björnsson and Pálsson 2008).

223

224

225

226

227

228

229

230

231

232

\section{How has ice recession affected volcanic activity in the past?}

\subsection{Evidence for accelerated volcanism triggered by deglaciation}

There is strengthening quantitative evidence linking periods of deglaciation with increased volcanic activity in many different volcanic settings. The best established and most dramatic acceleration in activity occurred in Iceland, where vigorous volcanism is strongly affected by a temperate ice sheet that may almost completely cover the island during glacial periods and almost completely disappear during interglacials (Björnsson and Pálsson 2008). Unloading of hundreds of metres to $2 \mathrm{~km}$ of ice 
233 during deglaciation in Iceland causes decompression that, according to current models, leads to a 234 greater degree and depth range of mantle melting (Jull and McKenzie 1996, Maclennan et al. 2002).

235 This is reflected in a 30- to 50-fold increase in the rate of magma eruption on individual volcanic 236 systems in the $1.5 \mathrm{ka}$ after the deglaciation of each area, inferred from the volume of erupted 237 deposits (Fig. 5; Maclennan et al. 2002). The short time delay between inferred ice unloading and 238 enhanced volcanism shows that the "extra" magma generated is rapidly transported from source to 239 surface without prolonged storage in magma chambers, so that Icelandic volcanism responds swiftly 240 to changes in ice thickness. In most other volcanic settings magma accumulation in chambers is the 241 norm (e.g. volcanic arcs), in which case the mechanism for enhanced volcanism may differ. It may 242 reflect the response of magma chambers to unloading, rather than the eruption of primitive melts 243 directly to the surface.

244 Statistical analyses of eruption databases have shown quantitatively that patterns of volcanic 245 activity elsewhere are also influenced by changes in ice thickness: both globally (Huybers and 246 Langmuir 2009, Fig. 6a), in Eastern California (Jellinek et al. 2004, Fig. 6b) and in western Europe 247 (Nowell et al. 2006). It is important to note that most statistical studies use a global climate proxy 248 from marine $\delta^{18} \mathrm{O}$ records as an indication of ice thickness changes, rather than local ice thickness 249 changes on volcanoes themselves (which are poorly constrained). Further, only the number of 250 eruptions is considered in analyses, rather the volume of eruptions. Huybers and Langmuir (2009) 251 used a database of global eruptions in the last $40 \mathrm{ka}$ (Siebert and Simkin 2002) to calculate the 252 change in frequency of eruptions with VEI $>2$ prior to, during and after the last deglaciation. The 253 increase in volcanic activity during deglaciation above modern values was found to be statistically 254 highly significant $(p<0.01)$ and activity during deglaciation $(18-7 \mathrm{ka})$ was significantly higher than 255 glacial rates between 40-20 ka. Although there are doubts about the completeness of the eruption 
record, interesting trends emerge from the data. The timing of enhanced volcanism differs between localities (e.g. a global increase occurred at $\sim 18 \mathrm{ka}$, but occurred later in Iceland, at $\sim 12 \mathrm{ka}$ ). This may reflect differing regional deglaciation histories, although other factors such as the delay between deglaciation and magma reaching the surface may also differ and depend upon the plumbing system of individual volcanic complexes. There is currently no discussion in the literature about whether the magnitude of volcanic eruptions increases during deglaciation, or whether it is only the frequency of eruptions that is affected.

Qualitative evidence for accelerated volcanism at individual volcanic complexes during deglaciation includes studies at Mt Mazama, western USA (Bacon and Lamphere 2006) and three Chilean volcanoes: Lascar, Puyehue and Nevados de Chillan (Gardeweg et al. 1998, Singer et al. 2008, Mee et al. 2009). However confidence about whether glacial-interglacial cycles truly influence eruptive activity is generally low, as there are insufficient dated eruptions at individual volcanoes to adequately test statistical significances. In some cases there is no obvious increase in activity during the last deglaciation (e.g. Torfajökull, Iceland; McGarvie et al. 2006).

\subsection{Edifice collapse triggered by ice recession}

A mechanistic link between deglaciation and collapse of ice-covered stratovolcanoes has been proposed by Capra (2008), who noted the coincidence between major edifice collapses and periods of rapid ice recession in the last $30 \mathrm{ka}$ for 24 volcanoes, predominantly located in Chile, Mexico and the USA. Capra proposed that abrupt climate change resulting in rapid ice melting may trigger edifice collapses through glacial debuttressing and an increase in fluid circulation and humidity. However, more data is required to quantitatively test whether periods of rapid ice decline do indeed correlate with acceleration in the incidence of edifice collapse. 


\section{How does the rate and extent of current ice melting compare with past changes?}

281 In order to assess whether the current changes in ice thickness and extent on many volcanoes are

282 likely to trigger accelerated volcanic activity the current rate of melting must be compared with

283 inferred rates of melting during the last deglaciation. Precisely reconstructing rates of ice thinning

284 during the last deglaciation is problematic, due to the limits of resolution provided by proxies for 285 changing ice extent and thickness. Furthermore, the history of deglaciation was complex, with major 286 stepwise advances and retreats including the Younger Dryas event at 11-10 ka and the Preboreal 287 Oscillation at 9.9-9.7 ka (Geirsdóttir et al. 2000).

Quoted "average" rates of deglaciation for Iceland, as used in mantle melting models, are 2 $\mathrm{m} \mathrm{a}^{-1}$ (2 km in $1 \mathrm{ka}$; Jull and McKenzie 1996, Pagli and Sigmundsson 2008). Similarly, the mean rate of surface elevation change of the Laurentide ice sheet during early Holocene deglaciation is estimated at $2.6 \mathrm{~m} \mathrm{a}^{-1}$ (Carlson et al. 2008). However, it is inappropriate to assume a constant rate of ice unloading, as phases of dramatic warming, such as the end of the Younger Dryas event, are likely to have involved much more rapid recession over shorter time intervals. Indeed, there is geological evidence for bursts of considerably faster deglaciation during abrupt warming events (e.g. $100 \mathrm{~m} \mathrm{a}^{-1}$ in Denmark between 18-17 ka, Humlum and Houmark-Nielsen, 1994). Rapid deglaciation in volcanically active areas could be further driven by positive feedback, with eruption-triggered jökulhlaups potentially playing an important role in glacier break-up (Geirsdóttir et al. 2000, 298 Carrivick et al. 2009b).

Nonetheless, it is informative to compare data: the current rates are mostly about $20-40 \%$ of

300 the mean estimated deglaciation rates for the Icelandic and Laurentide ice sheets (Fig. 7). The extent 301 of ice unloading is, however, very different, as rapid unloading has only occurred since the end of 
302 the Little Ice Age. For example, Vatnajökull in Iceland has only shrunk since 1890 (Björnsson and

303 Pálsson 2008, Pagli and Sigmundsson 2008). This means that total thinning of only $\sim 60 \mathrm{~m}$ has

304 occurred at Vatnajökull since 1890, compared with $2 \mathrm{~km}$ during the last deglaciation (Fig. 7).

305 Tropical glaciers in the Andes reached their maximum extents of the last millennium at between

3061630 and $1730 \mathrm{AD}$ (Jomelli et al. 2009) and have only rapidly retreated since the middle of the $19^{\text {th }}$

307 century. Therefore current thinning has only been sustained over a 100-200 year period, which is

308 considerably shorter than major deglaciation events. As a consequence the total reduction in ice

309 thickness to date during current warming is probably less than $10 \%$ of that during major past

310 deglaciation events.

311 However, there are marked local and regional discrepancies in how rapidly ice sheets and

312 glaciers have receded during current (post-Little Ice Age) warming. Over $3030 \mathrm{~km}^{3}$ if ice has been

313 lost from Glacier Bay, Alaska since 1770 (Larsen et al. 2005), with local thinning of up to $1.5 \mathrm{~km}$ at

314 a mean rate of up to $6.5 \mathrm{~m} \mathrm{a}^{-1}$. This value is more comparable to changes during the main phases of

315 deglaciation, but has not occurred in an active volcanic region.

316

317

318 5. How might hazards be affected by melting of ice and snow?

\subsection{Ice unloading may encourage more explosive eruptions}

321 The explosivity of eruptions beneath ice sheets is restrained by thick ice, as high glaciostatic

322 pressures (>5 MPa) inhibit volatile exsolution (Tuffen et al. 2010) and rapid ice deformation can

323 close cavities melted at the base of the ice, encouraging intrusive rather than explosive activity (Fig.

324 8; Tuffen et al. 2007). Thinning of ice covering a volcano may therefore encourage more explosive 
eruptions, which generate meltwater more rapidly than intrusive eruptions (Guðmundsson 2003)

and, if the ice surface were breached, create hazards associated with tephra. Where ice is thin $(<150$

m) there is generally comparatively little interaction between magma and meltwater, as thin ice

fractures readily, offers little constraint to the force of eruptions and is inefficient at collecting

meltwater around the vent (Smellie and Skilling 1994, Smellie 1999). Thinning of ice may therefore

generally lead to more explosive eruptions at volcanoes that are currently covered by substantial

thicknesses of ice (>300 m), especially those with deep ice-filled summit calderas such as Sollipulli,

Chile (Gilbert et al. 1996) and Katla, Iceland (Björnsson et al. 2000). It is important to note,

however, that there is currently no quantitative relationship between eruption explosivity and ice

thickness. The models quoted only simulate a small part of the coupled volcano-ice system and thus

are essentially qualitative; they do not incorporate feedbacks between the dynamics of magma storage, ascent and the response of the overlying ice.

\subsection{Ice unloading and increased melting may trigger edifice stability}

It has been hypothesised that melting and recession of ice on volcanic edifices may lead to instability and edifice collapse due to two independent mechanisms: firstly, debuttressing and the withdrawal of mechanical support from ice (Capra 2008) and secondly, an increase in the pore fluid pressure within

342 shallow hydrothermal systems, which may trigger movement on pre-existing weaknesses (Capra

343 2008). However, this hypothesis currently remains unproven due to insufficient data. A significant

344 proportion of glacier meltwater may enter the hydrothermal system of volcanoes (e.g. Antizana

345 volcano, Ecuador, Favier et al. 2008). Seasonal seismicity at volcanoes such as Mt Hood (USA) is

346 consistent with seismic triggering by an increase in meltwater input (Saar and Manga 2003), 
347 illustrating that movement on pre-existing weaknesses is favoured by enhanced meltwater

348 production.

\subsection{Melting of ice and snow may decrease the likelihood and magnitude of meltwater floods}

351 As the volume of ice and snow on a volcano decreases, the size of the reservoir of potential meltwater decreases. At volcanoes where a relatively small volume of ice and snow is present the total volume of lahars may be restricted by the volume of ice and snow available for melting

354 (Huggel et al. 2007a). This leads to the following qualitative prediction: as this volume decreases the total volume and magnitude of meltwater floods should decrease for a given size of eruption, thus reducing the associated hazards. Björnsson and Pálsson (2008) have shown that meltwater discharge

357 from thinning Icelandic glaciers is likely to peak in 2040-2050 as ablation rates rise, but thereafter recede, reflecting the diminished volume of ice available for melting. Futhermore, as meltwater floods are triggered when tephra falls onto ice and snow (Major and Newhall 1989, Walder 2000, Julio-Miranda et al. 2008), a reduction in the area of ice and snow will reduce the probability that

361 this will occur, therefore reducing the incidence of lahar generation. However, if the size of 362 eruptions were to increase then in some cases a dwindling ice volume would not prevent an increase 363 in the magnitude of meltwater floods, as recognised by Huggel et al. (2007a).

\section{What are the likely effects of $21^{\text {st }}$ century climate change on hazards at ice-covered} volcanoes?

368 Unloading as ice and snow melt may trigger increased volcanic activity. Vexed questions include

369 how quickly volcanic systems respond to ice thickness changes, which baselines for rates of volcanic 
370 activity are appropriate for the Holocene, and how to scale past accelerations in volcanic activity to

371 changes in the $21^{\text {st }}$ century.

372

373 6.1. Increased magma production and eruption in Iceland?

374 Melting of Icelandic ice sheets leads to increased mantle melting and eruption of magma to the

375 surface (Fig. 5; Jull and McKenzie 1996, Maclennan et al. 2002, Pagli and Sigmundsson 2008). It is

376 estimated that melting of Vatnajökull between 1890 and $2003\left(435 \mathrm{~km}^{3}\right.$ loss, with a thinning rate of

$377 \sim 0.5 \mathrm{~m} \mathrm{a}^{-1}$ ) led to a $1 \%$ increase in the rate of magma production (Pagli and Sigmundsson 2008). If

378 current melting rates continue throughout the $21^{\text {st }}$ century a roughly similar additional rise in melt

379 production may be anticipated. Any increase in the thinning rate would trigger a stronger

380 acceleration in melt production. It is important to note, however, that the rate and amount of ice

381 thinning are far lower than during the last deglaciation (Fig. 7), and the projected increases in the

382 rate of melt production are far weaker (at most a few percent increase, as opposed to a 30-50 fold

383 increase). Although studies have shown that additional melt was transported to the surface at a rate

384 of over $50 \mathrm{~m} \mathrm{a}^{-1}$ (Maclennan et al. 2002), this only constrains the timescale of melt extraction to

385 being $<2 \mathrm{ka}$.

386 There is incomplete evidence collected to date, but some preliminary data suggests that the

387 timing of Icelandic volcanism during deglaciation may have coincided with rapid warming events,

388 indicating a short delay between extra melting and eruption to the surface. The timing of large tuya-

389 building eruptions in north Iceland appear to correspond with two most marked warming events

390 during deglaciation - the Bolling warming and the end of the Younger Dryas (Licciardi et al. 2007). 
We therefore have insufficient knowledge to predict whether the "extra" melt generated would be erupted to the surface in the $21^{\text {st }}$ century and whether any statistically significant increase

393 in activity should be anticipated.

\subsection{Increased magma production and eruption globally?}

396 The pioneering study by Huybers and Langmuir (2009) attempts to relate changes in global volcanic 397 activity during deglaciation to estimates of the rate of ice unloading. In it they use a simple glacier 398 mass balance model to estimate modern changes in ice thickness at a number of glaciers. This model 399 considers only relative accumulation vs ablation rates and ignores the ice dynamical processes (e.g.

400 Bell 2008, Wingham et al. 2009) and local variations in precipitation and temperature (e.g. Vuille et 401 al. 2008) that strongly influence mass balance and ice sheet profiles (e.g. Hubbard 2006). The results 402 of eruption datasets are used to calculate glacial/deglacial and deglacial/Holocene eruption 403 frequency ratios (Fig. 6a). Volcanoes with a current strong negative ice volume balance are excluded 404 from the analysis as they are assumed not to have been ice-covered during the late Pleistocene, and 405 therefore insignificant ice unloading is assumed to have occurred during deglaciation. Analysis of 406 the eruption frequency of volcanoes considered to have been ice-covered then produces an 407 enhancement in the rate of volcanic activity by a factor of 2 and 6 between 12 and $7 \mathrm{ka}$. These 408 figures were generated using a $-6 \mathrm{~m} \mathrm{a}^{-1}$ and a $-9 \mathrm{~m} \mathrm{a}^{-1}$ cut-off, respectively. Estimates of the amount of increased melting and magma eruption to the surface are very 410 approximate. Huybers and Langmuir assume that unloading $1 \mathrm{~km}$ of ice above a $60 \mathrm{~km}$ thick melting

411 region triggers a $0.1 \%$ increase in the melt percentage, and that $10 \%$ of the melt then reaches the

412 surface. They then estimate that $15 \%$ of the $1.8 \times 10^{6} \mathrm{~km}^{3}$ of ice lost from mountain glaciers 413 between the last glacial maximum and today influences magma production. The validity of this 
414 percentage needs to be checked against the distribution of global ice loss from mountain glaciers,

415 which is itself very difficult to constrain due to a lack of data and the complexity of local climatic

416 variations (e.g. Vuille et al. 2008). The melting model also ignores diversity in melt zone depths and

417 does not take in account crustal storage in magma chambers.

418 Elsewhere, Jellinek et al. (2004) examine statistical correlations between changes in ice

419 thickness (assumed to be related to the time derivative of the SPECMAP $\delta^{18} \mathrm{O}$ record) and the

420 frequency (rather than magnitude) of documented volcanic eruptions in Eastern California (Fig. 6b).

421 They found a significant correlation, with increased frequency of volcanism following periods of

422 inferred glacier unloading. Models indicated a delay between unloading and increased volcanism of

$423 \quad 3.2 \pm 4.2 \mathrm{kyr}$ and $11.2 \pm 2.3 \mathrm{ka}$ for silicic and basaltic eruptions respectively. Although local ice

424 thickness fluctuations are unlikely to relate consistently or linearly to the oxygen isotope record, this

425 analysis does point to intriguing differences between the rate of response to unloading between

426 different magma types and volcanic plumbing systems. Similarly, Nowell et al. (2006) found

427 evidence for accelerated volcanism during deglaciation of western Europe.

428 These studies indicate that a statistically significant correlation exists between unloading of

429 ice and increased volcanism. However, as is the case for Iceland, the timescale of the response of

430 volcanic systems to ice unloading is not well constrained. Data from Eastern California suggest that

431 the volcanic response may be delayed by thousands of years. If this were the case, volcanism in the

432 coming century may reflect changing ice thicknesses in the mid-to-late Holocene, rather than

433 melting of ice since the Little Ice Age. Scaling issues are also problematic. There is considerable

434 uncertainty about how the magnitude of acceleration in melt production and magma eruption to the

435 surface scale to the amount and rate of ice unloading. A simple linear relationship between melt

436 production and unloading (e.g. Huybers and Langmuir 2009) is not appropriate as the rate of melt 
437 production also depends on the previous loading and unloading history (Jull and McKenzie 1996).

438 Furthermore, magma residence in chambers may decouple the timing of melt production from that of 439 magma eruption to the surface.

\subsection{Potential effects on volcanic hazards}

442 An increase in the rate of magma eruption to the surface would entail larger and/or more frequent 443 eruptions, thus increasing exposure to hazards. Indeed, analysis of tephra in the Greenland ice core 444 (Zielinski et al. 1996) has shown that the greatest frequency of volcanic events in the last $110 \mathrm{ka}$ occurred between 15 and $8 \mathrm{ka}$, closely corresponding to the timing of northern hemisphere deglaciation. The largest eruptions also occurred during a similar, overlapping interval, between 13 and $7 \mathrm{ka}$. To date most studies have focussed solely on the frequency of eruptions (e.g. Jellinek et al. 2004, Nowell et al. 2006, Huybers and Langmuir 2009). Increased eruptive frequency at a given volcano will increase risk exposure. The intensity and explosivity index (VEI) of eruptions also scale to their total volume (e.g. Newhall and Self 1982, Pyle 1999). There is currently insufficient evidence to determine whether the size or frequency of eruptions will increase in the $21^{\text {st }}$ century. The explosivity of eruptions beneath ice is expected to generally increase as the ice thins (Fig. 8; Tuffen et al. 2007). Therefore, where ice is over $150 \mathrm{~m}$ in thickness and thinning of more than $100 \mathrm{~m}$ occurs, the probability of more hazardous explosive eruptions will increase. This will be most relevant to volcanoes with deep ice-covered calderas such as Sollipulli, Chile (Gilbert et al. 1996). However, it is not currently possible to quantify the increased probability of explosive eruptions and whether it is significant.

There is stronger evidence that current ice recession may considerably increase hazards related to edifice instability. Capra (2008) has proposed that that the incidence of major volcano 
460 collapses is strongly affected by ice recession during deglaciation. Huggel et al. (2008) have noted

461 an upturn in the rate of large-volume avalanches, which corresponds with and is attributed to recent

462 climate change. Similar predictions are made for mountain instabilities due to recession of alpine

463 glaciers (Keiler et al., this volume). Melting and unloading of ice may have a much more rapid effect

464 on edifice stability than on melt production and eruption. Modelling by Huggel (2009) shows that

465 the thermal perturbations that may destabilize slopes are likely to occur over tens or hundreds of

466 years (for conductive heat flow processes) and years to decades (for advective/convective heat flow

467 processes). Perturbations triggered by volcanic activity may be effective over much shorter time 468 scales.

Andean stratovolcanoes that host rapidly-diminishing tropical glaciers are likely to be particularly sensitive to climate warming. Many glaciers are completely out of equilibrium with current climate and may completely disappear within decades (Vuille et al. 2008). Model projections of future climate change in the tropical Andes indicate a continued warming of the tropical troposphere throughout the 21 st century, with a temperature increase that is enhanced at higher elevations. By the end of the 21st century, following the SRES A2 emission scenario, the tropical Andes may experience a massive warming on the order of $4.5-5{ }^{\circ} \mathrm{C}$ (Vuille et al. 2008). This warming will drive edifice instability both by removing ice, increasing the amount of meltwater at high elevations on edifices and thawing ice-bedrock contacts, encouraging slippage. volumes of snow and ice from volcanoes such as Popocatepetl will reduce the volume of ice available for meltwater flood generation. Dwindling areas of ice and snow will also reduce the probability of lahar generation. This reduction in lahar hazards may only be notable in volcanoes undergoing almost complete glacier extinction (Huggel et al. 2007a). 


\section{Gaps in our knowledge and targets for future research}

485

486

487

488

489

490

491

492

493

494

495

496

497

498

499

500

501

502

503

504

505

506

Important gaps in our knowledge of links between melting of ice and volcanic hazards remain, which include:

1) Uncertainty about the timescale of volcanic responses to ice unloading. We currently have only limited insight into the reasons for delayed volcanic responses (Maclennan et al. 2002) and the timescales involved (Jellinek et al. 2004); response times are likely to differ in different tectonic settings.

2) Poor constraint on how ice bodies on volcanoes will respond to $21^{\text {st }}$ century climate change.

The highly localised effects of topography, microclimates and local geothermal and eruption-related processes on volcanoes conspire to create considerable diversity in the response of individual glaciers and ice sheets to climate change (e.g. Geirsdóttir et al. 2006, Rivera et al. 2006, Bown and Rivera 2007, Brock et al. 2007).

3) The sensitivity of volcanoes to small changes in ice thickness or to recession of small glaciers on their flanks is unknown. Although there is strong evidence that wholesale ice removal during deglaciation can significant accelerate volcanic activity there is considerable uncertainty about how volcanic responses to unloading scale with the magnitude, rate and distribution of ice unloading. A simple linear relationship between the rates of ice melting and additional melt production is unlikely to be appropriate. The effects of recession of different scales of ice body need to be considered, from the largest ice sheets to the smallest summit glaciers.

4) Lack of data on how past changes in ice thickness have affected the style of volcanic eruptions and associated hazards. Most statistical studies of the effects of ice thickness changes on volcanism 
507 have focussed exclusively on the frequency of eruptions. It would be of great interest to know

508 whether the sizes of eruptions or the probability of large caldera-forming events increase during

509 periods of ice recession.

510 5) It is not known how localised ice withdrawal from stratovolcanoes will affect shallow crustal

511 magma storage and eruption. Existing models for how loading by ice affects volcanism have

512 focussed on large ( $>50 \mathrm{~km}$ diameter), near-horizontal ice sheets and mantle melting (e.g. Jull and

513 McKenzie 1996, Pagli and Sigmundsson 2008). Stratovolcanoes, which constitute the vast majority

514 of ice- and snow-covered volcanoes worldwide, are entirely different systems, being characterised

515 by smaller, thinner ice bodies and the existence of crustal magma chambers.

516 6) Broader feedbacks between volcanism and climate change remain poorly understood.

517 A number of potential positive feedbacks during volcano-ice interactions exist, which could

518 potentially greatly magnify the rate of ice recession and effects on volcanic activity. Feedbacks

519 include the increased $\mathrm{CO}_{2}$ emissions from accelerated volcanism during ice unloading, which may

520 act to further warm the climate (Huybers and Langmuir 2009). Enhanced basal melting may

521 destabilise ice sheets, leading to more rapid ice recession (Bell 2008). More locally, tephra covering

522 the ice surface may affect the mass balance of glaciers (Rivera et al. 2006, Brock et al. 2007).

523 Currently little is known about the effects of these feedbacks and whether they will play an

524 important role in the $21^{\text {st }}$ century and beyond.

525

526 Future work required

527

528 In order to resolve these problems both new data and improved models are required. Existing

529 databases of known volcanic eruptions need to be augmented by numerous detailed case studies of 
530 the Quaternary eruptive history of ice-covered volcanoes, especially in the Andes, to determine

531 whether the frequency and size of their eruptions has been influenced by past changes in ice

532 thickness. The volcanic response should be examined to both large-magnitude, long timescale

533 climatic changes such as glacial-interglacial cycles and to smaller, briefer fluctuations in the last

534 millennium such as the Little Ice Age. This will reveal the sensitivity and response time of volcanic

535 systems to a range of forcing timescales and magnitudes.

536 The unique record of palaeo-ice thicknesses provided by subglacially erupted volcanic

537 deposits (e.g. Mee et al. 2006, Licciardi et al. 2007, Smellie et al. 2008, Tuffen et al. 2010) must be

538 exploited in order to precisely reconstruct fluctuating local ice thicknesses on volcanic edifices. In

539 tandem high resolution dating techniques will be required, which stretch the limits of existing

540 radiometric methods. Geochemical indicators of the residence time of magma in shallow magma

541 chambers could reveal whether shallow magma storage is affected by ice thickness variations.

542 Improved physical models are required to test how magma generation, storage and eruption

543 at stratovolcanoes is affected by stress perturbations related to the waxing and waning of small-

544 volume ice bodies on what is commonly steep topography. Finally, feedbacks between the mass

545 balance of ice sheets and glaciers and volcanic activity need to be incorporated into future Earth 546 System Models.

547

\section{Acknowledgements}

549 HT was supported by a NERC Research Fellowship [NE/E013740/1] and a NERC New Investigator

550 Grant [NE/G000654/1]. Thanks to Seb Watts, David Pyle, John Maclennan, Jasper Knight,

551 Freysteinn Sigmundsson, John Smellie and Jennie Gilbert for discussions and sharing materials.

552 Chris Kilburn is thanked for efficient and insightful editorial handling. 


\section{References}

556

557 Aðalgeirsdóttir, G., Guðmundsson, M. T. \& Björnsson, H. 2000 The response of a glacier

558 to a surface disturbance: a case study on Vatnajökull ice cap, Iceland. Ann. Glaciol. 31, 104-110.

559

560 Bacon, C. \& Lanphere, M. 2006 Eruptive history and geochronology of Mount Mazama and the

561 Crater Lake region, Oregon. Geol. Soc. Am. Bull. 118, 1331-1359.

562

563

Bell, R. E. 2008 The role of subglacial water in ice-sheet mass balance. Nature Geosci. 1, 297-304.

564 (DOI 10.1038/ngeo186).

565

566

567

Björnsson, H. 1998 Hydrological characteristics of the drainage system beneath a surging glacier. Nature 395, 771-774.

568

569

Björnsson, H. \& Pálsson, F. 2008 Icelandic glaciers. Jökull 58, 365-386.

570

571

572

Björnsson, H., Pálsson, F. \& Guðmundsson, M. T. 2000 Surface and bedrock topography of the 573

574 Bown, F. \& Rivera, A. 2007. Climate changes and recent glacier behaviour in the Chilean lake 575 district. Global Planet. Change 49, 79-86.

576

577 Brock, B., Rivera, A., Casassa G., Bown, F. \& Acuna, C. 2007 The surface energy balance of an

578 active ice-covered volcano: Villarrica Volcano, Southern Chile. Ann. Glaciol. 45, 104-114. 579

580 Capra, L. 2008 Abrupt climatic changes as triggering mechanisms of massive volcanic collapses. $J$. 581 Volcanol. Geotherm. Res. 155, 329-333. (DOI 10.1016/j.jvolgeores.2006.04.009). 
583 Capra, L., Poblete M. A., Alvarado, R. 2004 The 1997 and 2001 lahars of Popocatepetl volcano

584 (Central Mexico): textural and sedimentological constraints on their origin and hazards. J. Volcanol.

585 Geotherm. Res. 131, 351-369.

586

587 Carlson, A. E., Legrande, A. N., Oppo, D. W., Came, R. E., Schmidt, G. A., Anslow, F. S.,

588 Licciardi, J. M. \& Obbink, E. A. 2008 Rapid early Holocene deglaciation of the

589 Laurentide ice sheet. Nature Geosci. 1, 620-624. (DOI 10.1038/ngeo285).

590

591 Carrasco-Núñez G.,Vallance J. W. \& Rose W. I. 1993 A voluminous avalanche-induced lahar from

592 Citlaltépetl volcano, Mexico. Implications for hazard assessment. J. Volcanol. Geotherm. Res. 59, $59335-46$.

594

595 Carrivick, J. L. 2007 Hydrodynamics and geomorphic work of jökulhlaups (glacial outburst floods)

596 from Kverkfjöll volcano, Iceland. Hyd. Proc. 21, 725-740.

597

598 Carrivick, J. L., Manville, V. \& Cronin, S. 2009a Modelling the March 2007 lahar from Mt

599 Ruapehu. Bull. Volcanol. 71, 153-169.

600

601 Carrivick, J. L., Russell, A. J., Rushmer, E. L., Tweed, F. S., Marren, P. M., Deeming, H. \& Lowe,

602 O. J. 2009b. Geomorphological evidence towards a deglacial control on volcanism. Earth Surf. Proc.

603 Land. 34, 1164-1178. (DOI 10.1002/esp.1811).

604

605 Carrivick, J. L., Russell, A. J., Tweed, F. S. \& Twigg, D., 2004 Palaeohydrology and sedimentology 606 of jökulhlaups from Kverkfjöll, Iceland. Sed. Geol. 172, 19-40.

607

608 Ceballos, J. L. Euscátegui, C., Ramírez, J., Cañon M., Huggel, C., Haeberli, W., Machguth, H. 2006

609 Fast shrinkage of tropical glaciers in Colombia. Ann. Glaciol. 43, 194-201.

610

611 Corr, H. F. J. \& Vaughan, D. G. 2008 A recent volcanic eruption beneath the West Antarctic ice 612 sheet. Nature Geosci. 1, 122-125. (DOI 10.1038/ngeo106).

613 
614 Eliasson, J., Larsen, G., Gudmundsson, M.T., Sigmundsson, F. 2006 Probabilistic model

615 for eruptions and associated floods events in the Katla caldera, Iceland. Comp. Geosci. 10, 179-200.

616

617 Favier V., Coudrain, A., Cadier, E., Francou, B., Ayabaca, E., Maisincho, L., Praderio, E., Villacis,

618 M. \& Wagnon, P. 2008 Evidence of groundwater flow on Antizana ice-covered volcano, Ecuador.

619 Hydrol. Sci. 53, 278-291.

620

621 Gardeweg, M. C, Sparks, R. S. J. \& Matthews, S. J. 1998 Evolution of Lascar volcano, northern

622 Chile. J. Geol. Soc. Lond. 155, 89-104.

623

624 Geirsdóttir, Á., Johannesson, T., Björnsson, H., et al. 2006 Response of Hofsjökull and southern 625 Vatnajökull, Iceland, to climate change. J. Geophys. Res. 111, art. no. F03001.

626

627 Geirsdóttir, Á, Hardardóttir, J. \& Sveinbjörnsdóttir, Á. E. 2000 Glacial extent and catastrophic 628 meltwater events during the deglaciation of Southern Iceland. Quat. Sci. Rev. 19, 1749-1761.

629

630 Gilbert, J. S., Stasiuk, M. V., Lane, S. J., Adam, C. R., Murphy, M. D., Sparks, R. S. J. \& Naranjo, J. 631 A. 1996 Non- explosive, constructional evolution of the ice-filled caldera at Volcán Sollipulli, Chile. 632 Bull. Volcanol. 58, 67-83

633

634 Guðmundsson, M. T. 2003. Melting of ice by magma-ice-water interactions during subglacial 635 eruptions as an indicator of heat transfer in subaqueous eruptions. In: White, J.D.L., Smellie, J.L.

636 and Clague, D., eds. Explosive Subaqueous Volcanism, AGU Geophysical Monograph, 140, 61-72. 637

638 Guðmundsson, M. T., Larsen, G., Höskuldsson, A., et al. 2008 Volcanic hazards in Iceland. Jökull $63958,251-268$.

640

641 Guðmundsson, M. T., Sigmundsson, F. \& Björnsson, H. 1997 Ice-volcano interaction of the 1996

642 Gjálp subglacial eruption, Vatnajökull, Iceland. Nature 389, 954-957.

643 
644 Guðmundsson, M. T., Sigmundsson, F., Björnsson, H. \& Högnadóttir, P. 2004 The 1996 eruption at 645 Gjálp, Vatnajökull ice cap, Iceland: Course of events, efficiency of heat transfer, ice deformation and 646 subglacial water pressure. Bull. Volcanol., 66, 46-65.

647

648 Guðmundsson, S., Björnsson, H., Johannesson, T., et al. 2009 Similarities and differences in the 649 response to climate warming of two ice caps in Iceland. Hydrol. Res., 40, 495-502.

650

651 Hoblitt, R. P., Walder, J. S., Driedger, C. L., Scott, K. M., Pringle, P. T. \& Vallance, J.W. 1998

652 Volcano Hazards from Mount Rainier, Washington, Revised 1998. U.S. Geol. Surv. Open-File 653 Report 98-428.

654

655 Houghton, B. F., Latter, J. H. \& Hackett, W.R. 1987 Volcanic hazard assessment for Ruapehu 656 composite volcano, Taupo volcanic zone, New Zealand. Bull. Volcanol. 49, 737-751.

657

658 Hubbard, A. 2006 The validation and sensitivity of a model of the Icelandic ice sheet. Quat. Sci.

659 Rev. 25, 2297-2313.

660

661 Hubbard, B.E., Sheridan, M.F., Carrasco-Nuñez, G., Díaz-Castellon, R., Rodríguez, S.R. 2007

662 Comparative lahar hazard mapping at Volcan Citlaltépetl, Mexico using SRTM, ASTER and DTED6631 digital topographic data. J. Volcanol. Geotherm. Res. 160, 99-124.

664

665 Huggel, C. 2009 Recent extreme slope failures in glacial environments: effects of thermal 666 perturbation. Quat. Sci. Rev. 28, 1119-1130.

667

668 Huggel, C., Caplan-Auerbach, J. \& Wessels, R. 2008 Recent extreme avalanches: triggered by 669 climate change? EOS, Trans. Am.Geophys. Union, 89, 469-470.

670

671 Huggel, C., Ceballos J. L., Pulgarin B., Ramirez, J. \& Thouret J.-C. 2007a Review and reassessment 672 of hazards owing to volcano-glacier interactions in Colombia. Ann. Glaciol. 45 128-136, 2007. 673 
674 Huggel, C., Caplan-Auerbach, J., Waythomas, C.F. \& Wessels, R.F. 2007b Monitoring and

675 modeling ice-rock avalanches from ice-capped volcanoes: A case study of frequent large avalanches

676 on Iliamna Volcano, Alaska. J. Volcanol. Geotherm. Res. 168, 114-136.

677

678 Humlum, O. \& Houmark-Nielsen, M. 1994 High deglaciation rates in Denmark during the Late

679 Weichselian - implications for the palaeoenvironment. Geograf. Tidsskrift 94, 26-37.

680

681 Huybers, P. \& Langmuir, C. 2009 Feedback between deglaciation, volcanism, and atmospheric $\mathrm{CO}_{2}$.

Earth Planet. Sci. Lett. 286, 479-491.

683

684 Jarosch, A. H. \& Gudmundsson, M. T. 2007 Numerical studies of ice flow over subglacial

685 geothermal heat sources at Grímsvötn, Iceland, using the full Stokes equations. J. Geophys. Res.

686 112, F2, F02008.

687

688 Jellinek A. M., Manga, M., Saar, M. O. 2004 Did melting glaciers cause volcanic eruptions in 689 eastern California? Probing the mechanics of dike formation. J. Geophys. Res. 109, B09206. (DOI $69010.1029 / 2004 J B 002978)$.

691

692 Jomelli, V., Favier, V., Rabatel, A., Brunstein, D., Hoffmann, G. \& Francou, B. 2009 Fluctuations of 693 glaciers in the tropical Andes over the last millennium and palaeoclimatic implications: A review.

694 Palaeogeog. Palaeoclim. Palaeoecol. 281, 269-282.

695

696 Jordan, E., Ungerechts, L., Caceres, B., Penafiel, A. \& Francou, B. 2005 Estimation by

697 photogrammetry of the glacier recession on the Cotopaxi volcano (Ecuador) between

6981956 and 1997. Hyd. Sci. J. 50, 949-961.

699

700 Julio-Miranda, P., Delgado-Granados, H., Huggel, C., et al. 2008 Impact of the eruptive activity on 701 glacier evolution at Popocatepetl Volcano (Mexico) during 1994-2004. J. Volcanol. Geotherm. Res. 702 170, 86-98.

703 
704 Jull, M. \& McKenzie, D. P. 1996 The effect of deglaciation on mantle melting beneath Iceland. J.

705 Geophys. Res. 101, 21815-21828.

706

707 Keiler, M., Knight, J. \& Harrison, S. (this issue) Climate change and geomorphological hazards in 708 the eastern European Alps.

709

710 Larsen C. F., Motyka, R. J., Freymueller, J. T., Echelmeyer, K. A. \& Ivins E. I. 2005 Rapid

711 viscoelastic uplift in southeast Alaska caused by post-Little Ice Age glacial retreat. Earth Planet. Sci.

712 Lett. 237, 548-560.

713

714 Lescinsky, D. T. \& Fink, J. H. 2000 Lava and ice interaction at stratovolcanoes: use of characteristic 715 features to determine past glacial extents and future volcanic hazards. J. Geophys. Res. 105, 2371171623726.

717

718 Licciardi, J. M., Kurz, M. D. \& Curtice, J. M. 2007 Glacial and volcanic history of Icelandic table 719 mountains from cosmogenic ${ }^{3} \mathrm{He}$ exposure ages. Quat. Sci.Rev. 26, 1529-1546.

720

721 Lythe, M. B. \& Vaughan, D. G. 2001 BEDMAP: A new ice thickness and subglacial topographic 722 model of Antarctica. J. Geophys. Res. 106, 11335-11352.

723

724 Maclennan, J., Jull, M., McKenzie, D. P., Slater, L. \& Gronvold, K. 2002 The link between 725 volcanism and deglaciation in Iceland. Geochem. Geophys. Geosyst., 3, 1062. (DOI 10.1029/2001GC000282).

727

728

McGarvie, D. W., Burgess, R., Tindle, A. J., Tuffen, H. \& Stevenson, J. A. 2006 Pleistocene

729 rhyolitic volcanism at the Torfajökull central volcano, Iceland: eruption ages, glaciovolcanism, and 730 geochemical evolution. Jökull 56, 57-75.

731

732 Magnusson, E., Björnsson, H., Dall, J., et al. 2005 Volume changes of Vatnajökull ice cap, Iceland, 733 due to surface mass balance, ice flow, and subglacial melting at geothermal areas. Geophys. Res. 734 Lett. 32, art. no. L05504. 
736 Major, J. J \& Newhall, C. G. 1989 Snow and ice perturbation during historical volcanic eruptions and the formation of lahars and floods. Bull. Volcanol. 52, 1-27.

Mathews, W. H. 1951 The Table, a flat-topped volcano in southern British Columbia. Am. J. Sci.

Mee, K., Gilbert, J. S., McGarvie, D. W., Naranjo, J. A. \& Pringle, M. 2009 Palaeoenvironment reconstruction, volcanic evolution and geochronology of the Cerro Blanco subcomplex, Nevados de

744 Chillán Volcanic Complex, central Chile. Bull. Volcanol. 71, 933-952. (DOI 10.1007/s00445-009745 0277-7).

Mee, K., Tuffen, H. \& Gilbert, J. S. 2006 Snow-contact volcanic facies at Nevados de Chillan volcano, Chile, and implications for reconstructing past eruptive environments. Bull. Volcanol. 68 , 749 363-376

750

Newhall, C.G., Self, S. 1982 The volcanic explosivity index (VEI): An estimate of explosive 752 magnitude for historical volcanism. J. Geophys. Res. 87, 1231-1238.

753

754

Noe-Nygaard, A. 1940 Sub-glacial volcanic activity in ancient and recent times (studies in the 755 palagonite system of Iceland, no. 1). Folia Geog. Dan. 1, 1-67.

756

757

Nowell, D., Jones, C. \& Pyle, D. 2006 Episodic quaternary volcanism in France and Germany. $J$. 758 Quat. Sci. 21, 645-675.

759

760 Pagli, C. \& Sigmundsson, F. 2008 Will present day glacier retreat increase volcanic activity? Stress

761 induced by recent glacier retreat and its effect on magmatism at the Vatnajökull ice cap, Iceland.

762 Geophys. Res. Lett. 35: art. no. L09304.

763

764 Pierson, T. C., Janda, R. J., Thouret J.-C. \& Borrero, C. A. 1990 Perturbation and melting of snow 765 and ice by the 13 November 1985 eruption of Nevado del Ruiz, Colombia, and consequent 
mobilization, flow, and deposition of lahars. J. Volcanol. Geotherm. Res., 41, 17-66.

Pyle, D. M. 1999 Sizes of volcanic eruptions. In: H. Sigurdsson (Editor), Encyclopaedia of

Volcanoes. Academic Press, San Diego, pp. 263-269.

770

771

Rivera, A., Bown, F., Mella, R., Wendt, J., Casassa, G., Acuña, C., Rignot, E., Clavero, J., Brock, B.

772

2006 Ice volumetric changes on active volcanoes in Southern Chile. Ann. Glaciol. 43, 111-122.

773

774

Saar, M. O. \& Manga, M. 2003 Seismicity induced by seasonal groundwater recharge at Mt. Hood,

775

Oregon. Earth Planet. Sci. Lett. 214, 605-618.

776

777

Shepherd, A., Wingham, D. J., Mansley, J. A. D. \& Corr, H. F. J. 2001 Inland thinning of Pine

778

Island Glacier, West Antarctica. Science, 291, 862-864. (DOI 10.1126/science.291.5505.862).

779

780

Siebert, L. \& Simkin, T. 2002 Volcanoes of the world: an illustrated catalog of Holocene volcanoes 781 and their eruptions. Smithsonian Institution, Global Volcanism Program, Digital Information Series, 782 GVP-3.

783

784

785

786

787

788

789

790

791

792

Smellie, J. L. 1999 Subglacial eruptions. In: H. Sigurdsson (Editor), Encyclopaedia of Volcanoes.

Smellie, J. L. \& Skilling, I. P. 1994 Products of subglacial volcanic eruptions under different ice thicknesses - 2 examples from Antarctica. Sed. Geol. 91, 115-129.

793

794 Smellie, J. L., 2008. Basaltic subglacial sheet-like sequences: evidence for two types with different 795 implications for the inferred thickness of associated ice. Earth Sci. Rev. 88, 60-88. 
797 Smellie, J. L., Johnson, J. S., McIntosh, W. C., Esserb, R., Gudmundsson, M. T., Hambrey, M. J. \&

798 van Wyk de Vries, B., 2008. Six million years of glacial history recorded in volcanic lithofacies of 799 the James Ross Island Volcanic Group, Antarctic Peninsula. Palaeogeog. Palaeoclim. Palaeoecol.

$800 \quad 260,122-148$.

801

802 Thompson, L. G., Brecher, H. H., Mosley-Thompson, E., Hardy, D. R. \& Mark, B. G. 2009 Glacier 803 loss on Kilimanjaro continues unabated. Proc. Nat. Acad. Sci. 106, 19770-19775. (DOI

804 10.1073/pnas.0906029106).

805

806 Tuffen, H. 2007 Models of ice melting and edifice growth at the onset of subglacial

807 basaltic eruptions. J. Geophys. Res. 112, art. no. B03203. (DOI 10.1029/

808 2006JB004523).

809

810 Tuffen, H. \& Castro, J. M. 2009. An obsidian dyke erupted through thin ice: Hrafntinnuhryggur,

811 Krafla, Iceland. J. Volcanol. Geotherm. Res. 185, 352-366.

812

813 Tuffen, H., Gilbert J. S., McGarvie, D. W. 2007 Will subglacial rhyolite eruptions be explosive or 814 intrusive? Some insights from analytical models. Ann. Glaciol. 45, 87-94.

815

816 Tuffen, H., Owen, J. \& Denton, J. S. 2010 Magma degassing during subglacial eruptions and its use 817 to reconstruct palaeo-ice thicknesses. Earth Sci. Rev., doi: 10.1016/j.earscirev.2010.01.001.

818

819 Vuille, M., Francou, B., Wagnon, P., Juen, I., Kaser, G., Mark, B. G. \& Bradley, R. S. 2008 Climate 820 change and tropical Andean glaciers -past, present and future. Earth Sci. Rev. 89, 79-96.

821

822 Waitt, R. B. 1989 Swift snowmelt and floods (lahars) caused by great pyroclastic surge at Mount St 823 Helens volcano, Washington, 18 May 1980. Bull. Volcanol. 52, 138-157. (DOI

824 10.1007/BF00301553).

825

826 Walder, J. S. 2000 Pyroclast/snow interactions and thermally driven slurry formation. Part 1: Theory 827 for monodisperse grain beds. Bull. Volcanol. 62, 105-118. 
829 Waythomas, C. F. \& Miller, T. P., 1999 Preliminary volcano-hazard assessment for Iliamna

830 Volcano, Alaska. U.S. Geol. Surv. Open-file Report, 99-373, 31 pp.

831

832 Wingham, D. J., Wallis, D. W. \& Shepherd, A. 2009 Spatial and temporal evolution of Pine Island 833 Glacier thinning, 1995-2006. Geophys. Res. Lett. 36, L17501. (DOI 10.1029/2009GL039126).

834

835 Zielinski, G., Mayewski, P., Meeker, L., Whitlow, S. \& Twickler, M. A. 1996 110,000-yr record of 836 explosive volcanism from the GISP2 (Greenland) ice core. Quat. Res. 45, 109-118. 


\section{$838 \quad$ Figure captions}

839

840 Figure 1. (a) Explosive phreatomagmatic activity at Grímsvötn, Iceland on $2^{\text {nd }}$ November 2004.

841 Photograph by Matthew Roberts, Icelandic Meteorological Office. (b) A small plume of ash and

842 steam at the ice-covered summit of Mt Redoubt, Alaska in March 2009 (photograph by Alaska

843 Volcano Observatory). (c) Lahar and flood deposits in the Drift River Valley following eruptions at

844 Mt Redoubt in 2009. Photograph by Game McGimsey, AVO/USGS. (d) Aerial view of lahar

845 deposits that destroyed the town of Armero in 1985 after the eruption of Nevado del Ruiz, Columbia.

846 Photograph by R.J. Janda, USGS.

847

848 Figure 2. (a) Iliamna Volcano, Alaska, showing the path of an ice-rock avalanche that originated 849 from a geothermally active zone high in the summit region. From Huggel 2009, photograph by R.

850 Wessels. (b) Map of Myrdalsjökull ice cap, Iceland, showing potential drainage directions of

851 jökulhlaups triggered by eruptions at the ice-covered Katla volcano (from Eliasson et al. 2006).

852

853 Figure 3. Dramatic loss of snow and ice from the summit of Kilimanjaro between 2000 and 2007, 854 from Thompson et al. (2009).

855

856 Figure 4. (a) Disruption of ice at the site of the 1998 Grímsvötn eruption, Vatnajökull, Iceland.

857 Photograph by Magnus Tumi Guðmundsson. (b) Tephra-covered blocks of ice were a last remnant 858 of a now-extinct glacier on Popocatepetl in 2004. From Julio-Miranda et al. (2008).

859 
860 Figure 5. Modelled acceleration in melting of the Icelandic mantle during the last deglaciation (from

861 Maclennan et al. 2002). (a) Increased rate of melting vs depth in the mantle. The melting rate is the

862 volume of melt produced from each unit volume of mantle per kyr. (b) Modelled rate of melt

863 production with a "spike" between 12 and $11 \mathrm{ka}$.

864

865 Figure 6. a) The ratio of postglacial (18-7 ka) to glacial (40-20 ka) activity at volcanoes worldwide 866 plotted against a proxy for the amount of ice unloading from ice mass balance models (Huybers and

867 Langmuir 2009). Regions with a less negative ice volume balance are those that are most likely to

868 have been glaciated, and thus have experienced significant unloading of ice during the last

869 deglaciation. It is at these regions that the strongest acceleration in the rate of eruptions has occurred, 870 suggesting a causal link between unloading of ice and enhanced volcanic activity. b) Data from

871 Jellinek et al. (2004) showing the SPECMAP $\delta^{18} \mathrm{O}$ curve (a proxy for global ice volume) and the

872 time series of eruptions in the Long Valley and Owens Valley volcanic fields, California. This data

873 is used to show statistically significant correlation between ice unloading and accelerated volcanism.

874

875 Figure 7. Some approximate rates and amounts of ice thinning since the Little Ice Age and during 876 deglaciation, together with projections for the $21^{\text {st }}$ century using current rates of ice melting. Note 877 that total thinning may in many cases be limited by the complete extinction of ice (e.g. Popocatepetl, 878 Julio-Miranda et al. 2008).

879

880 Figure 8. Results of modelling of rhyolitic eruptions under ice from a $1.5 \mathrm{~km}$-long fissure. The

881 evolution of subglacial cavities during melting and ice deformation is simulated and the combination 882 of ice thickness and magma discharge rate likely to lead to explosive and intrusive eruptions is 
883 indicated. Explosive eruptions (above the line) are favoured by thin ice and high magma discharge 884 rates. They are more hazardous than intrusion eruptions since meltwater is produced far more 885 quickly (Guðmundsson 2003) and eruptions may pierce the ice surface, producing tephra hazards. 886 Modified from Tuffen et al. (2007).

887 
888 Figure 1.

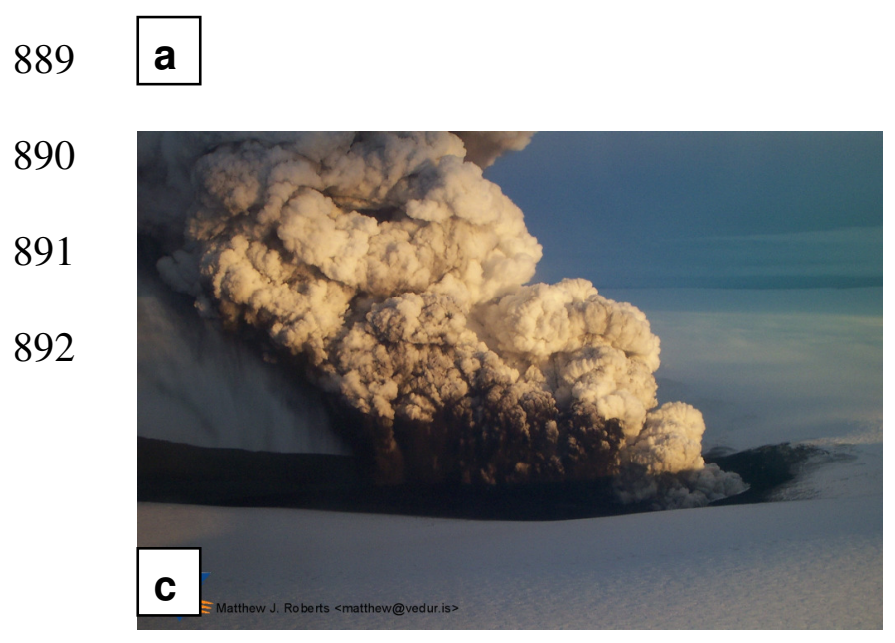

\section{b}
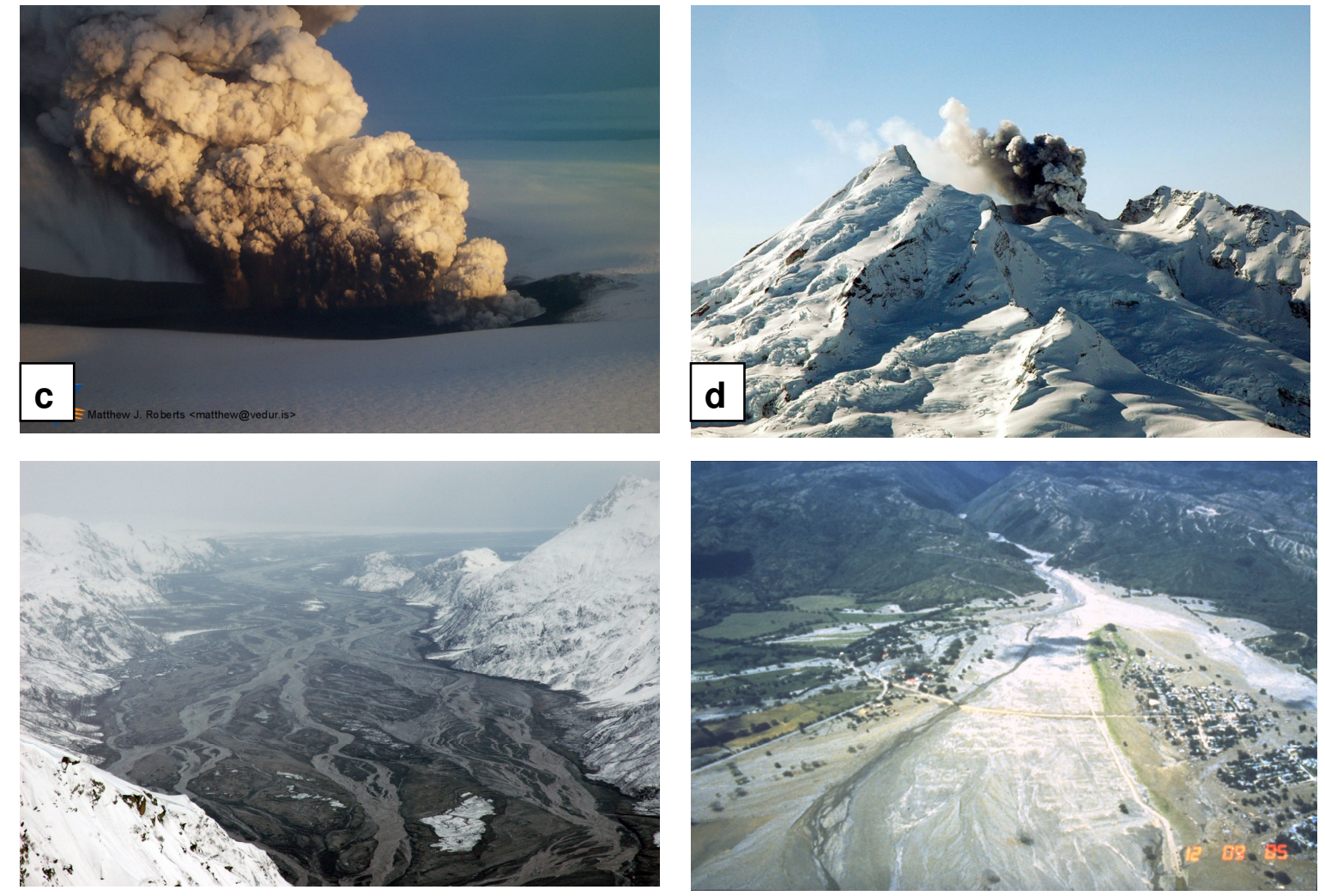


\section{$893 \quad$ Figure 2.}

894

895

896

897

898

899

900

901

902

903

904

905

906

907

908

909

910

911

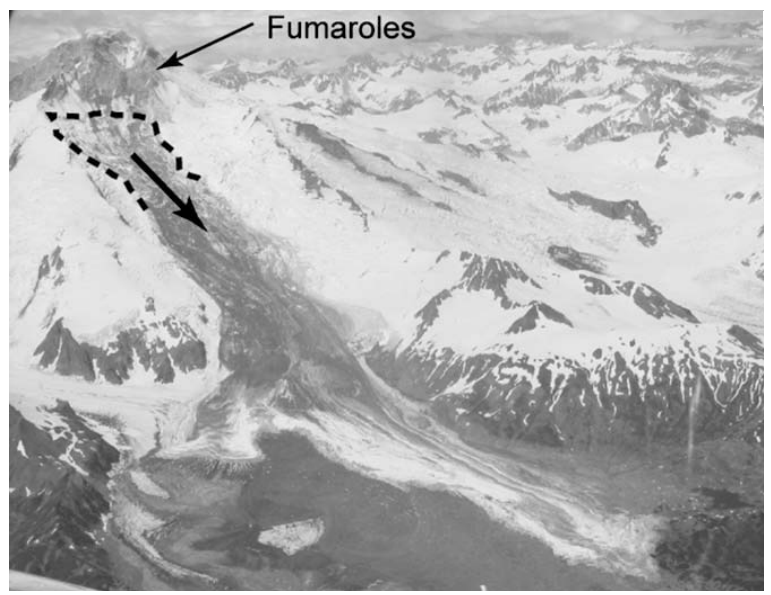

(a)

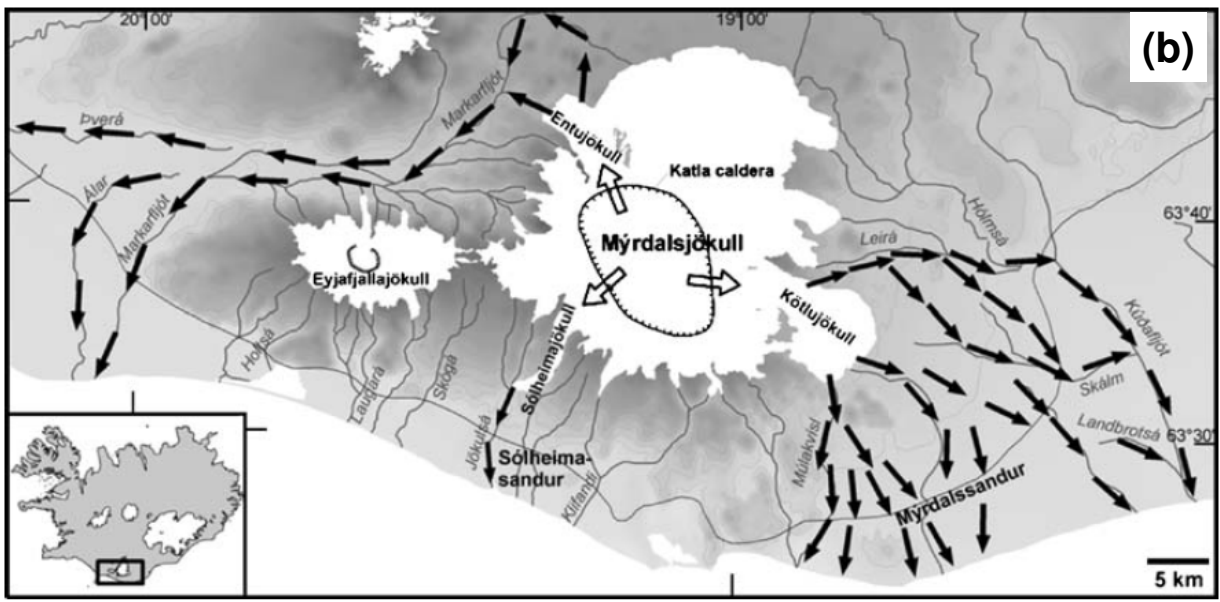

912

913

914

915

916 
$917 \quad$ Figure 3.

918

919
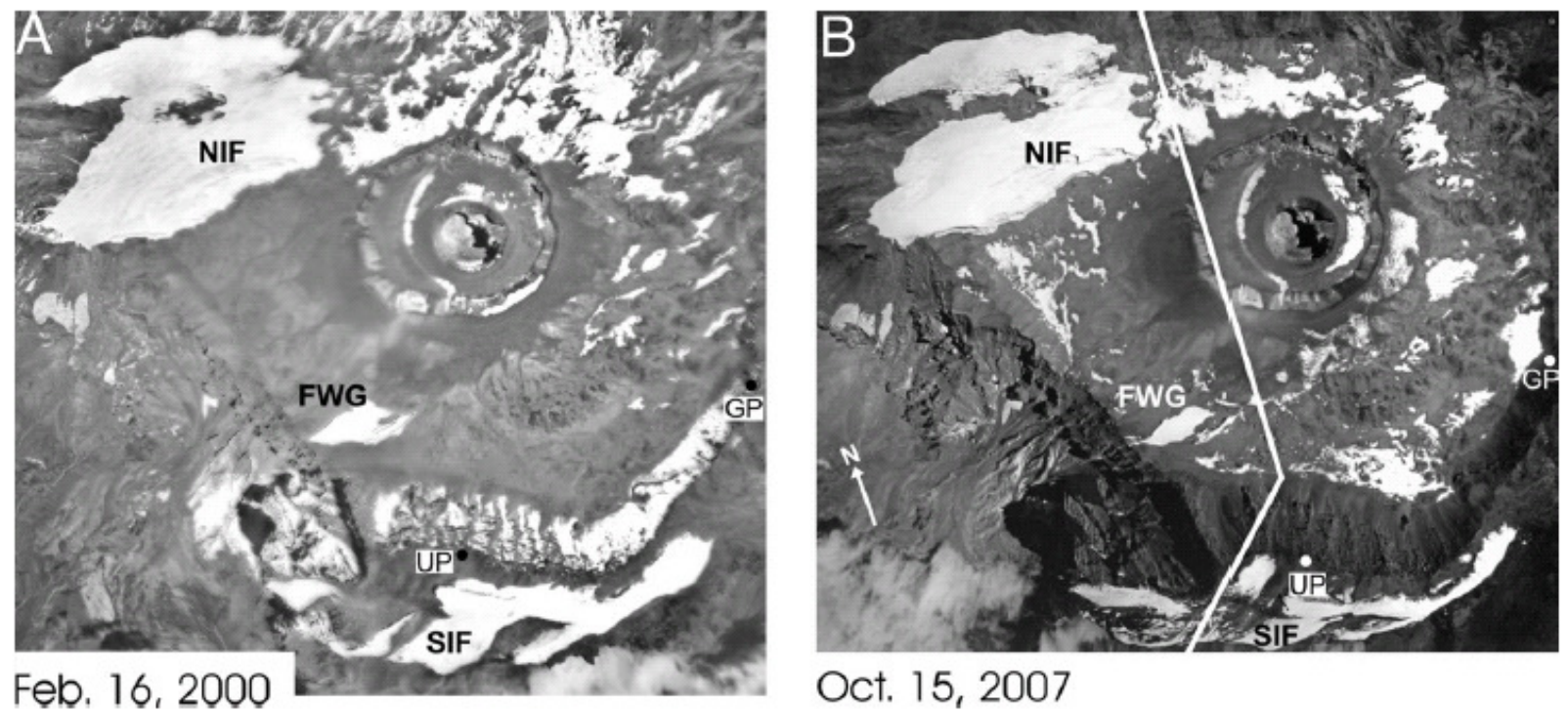

Oct. 15, 2007 
$920 \quad$ Figure 4.

921

${ }^{922} \mathbf{a}$
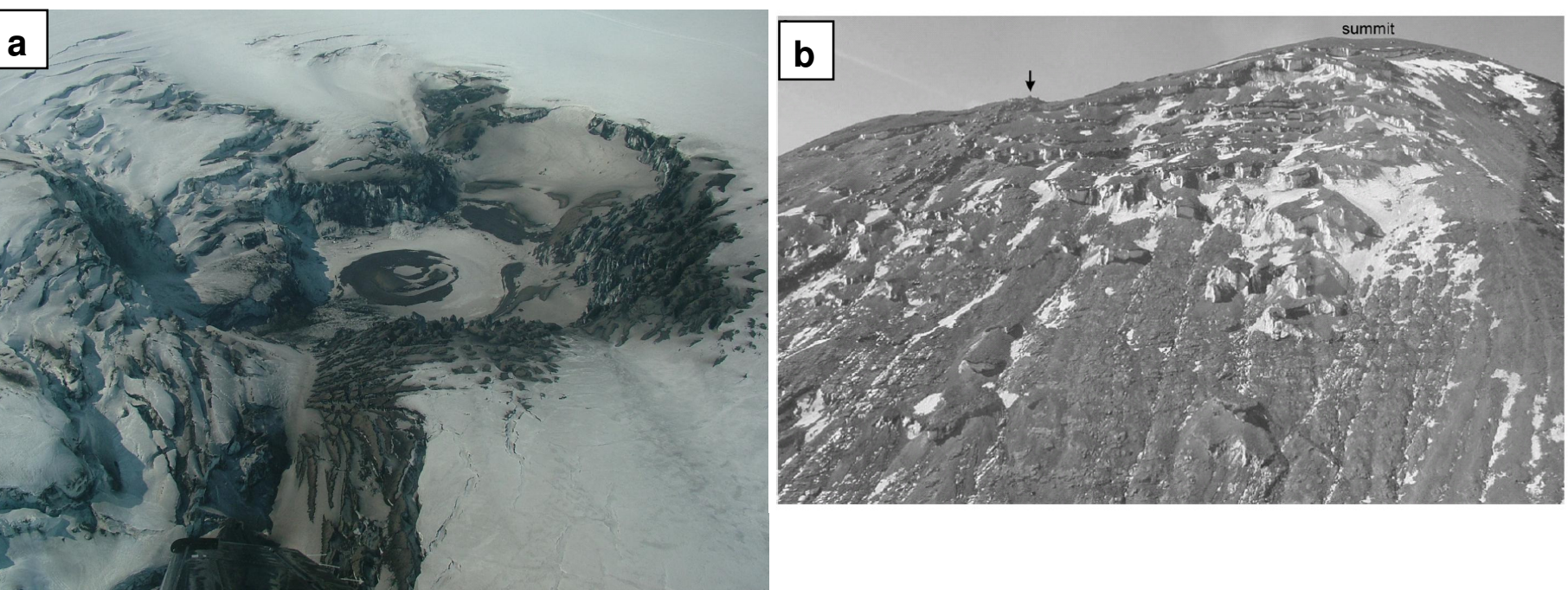
$923 \quad$ Figure 5.
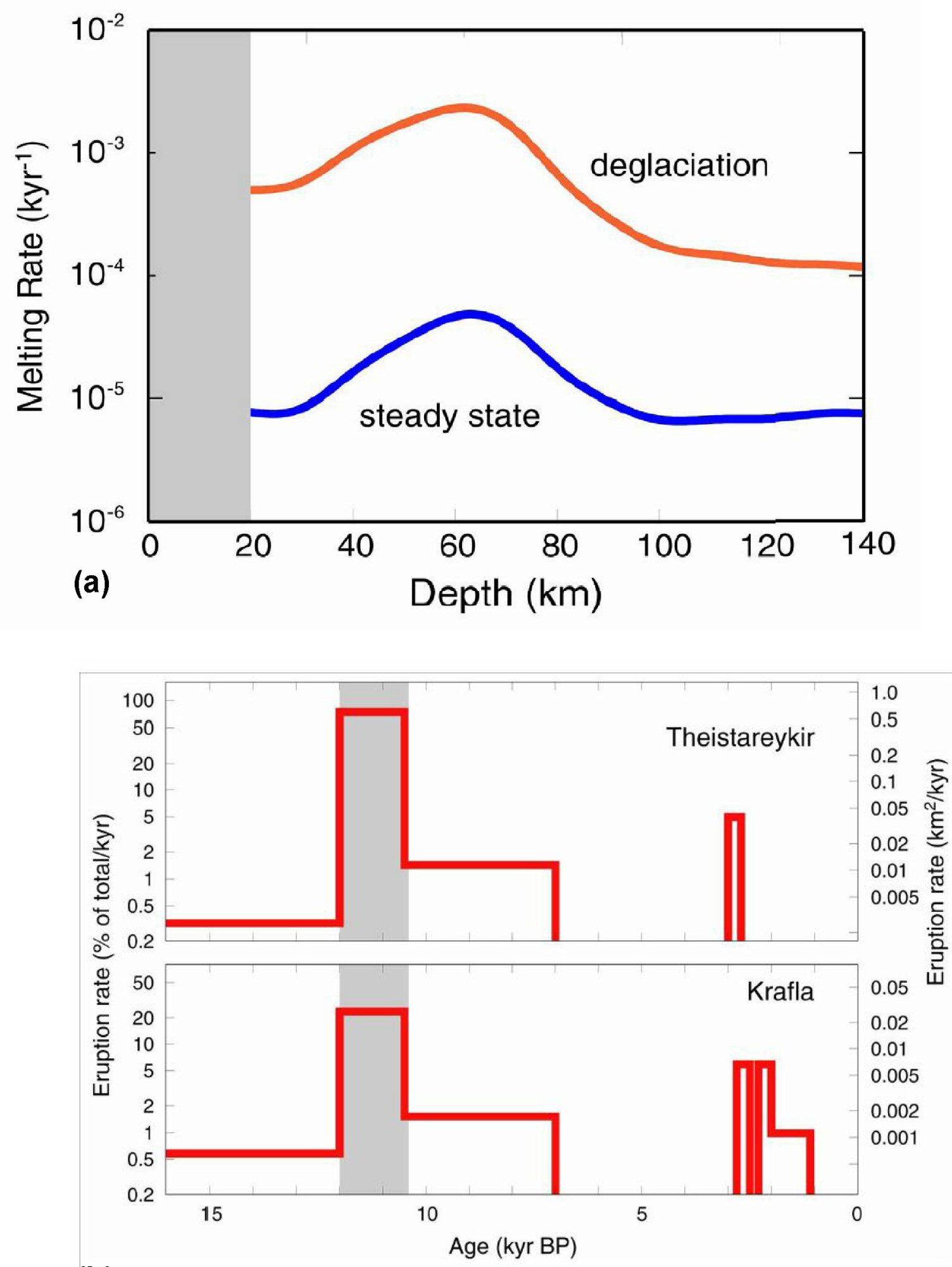

924

(b) 
Figure 6

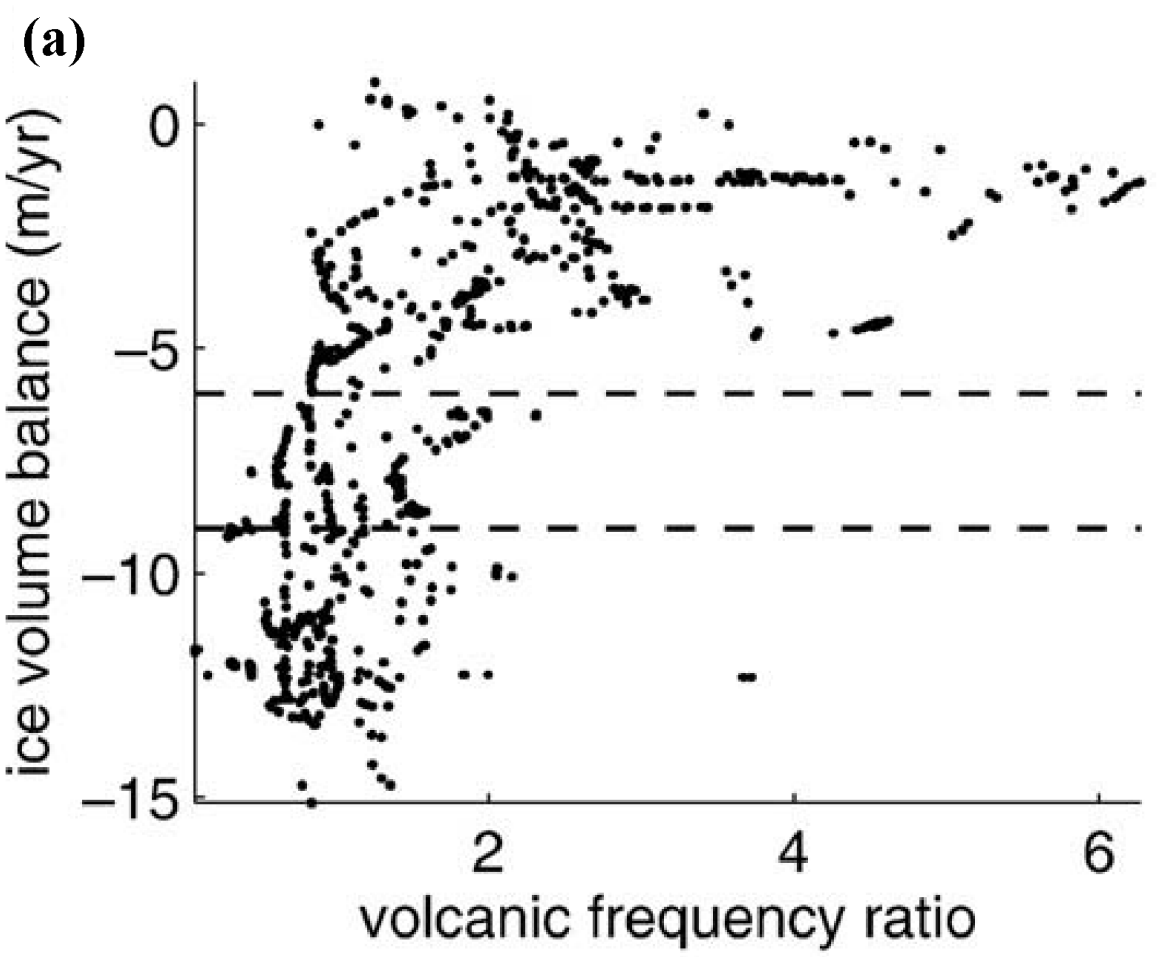

(b)

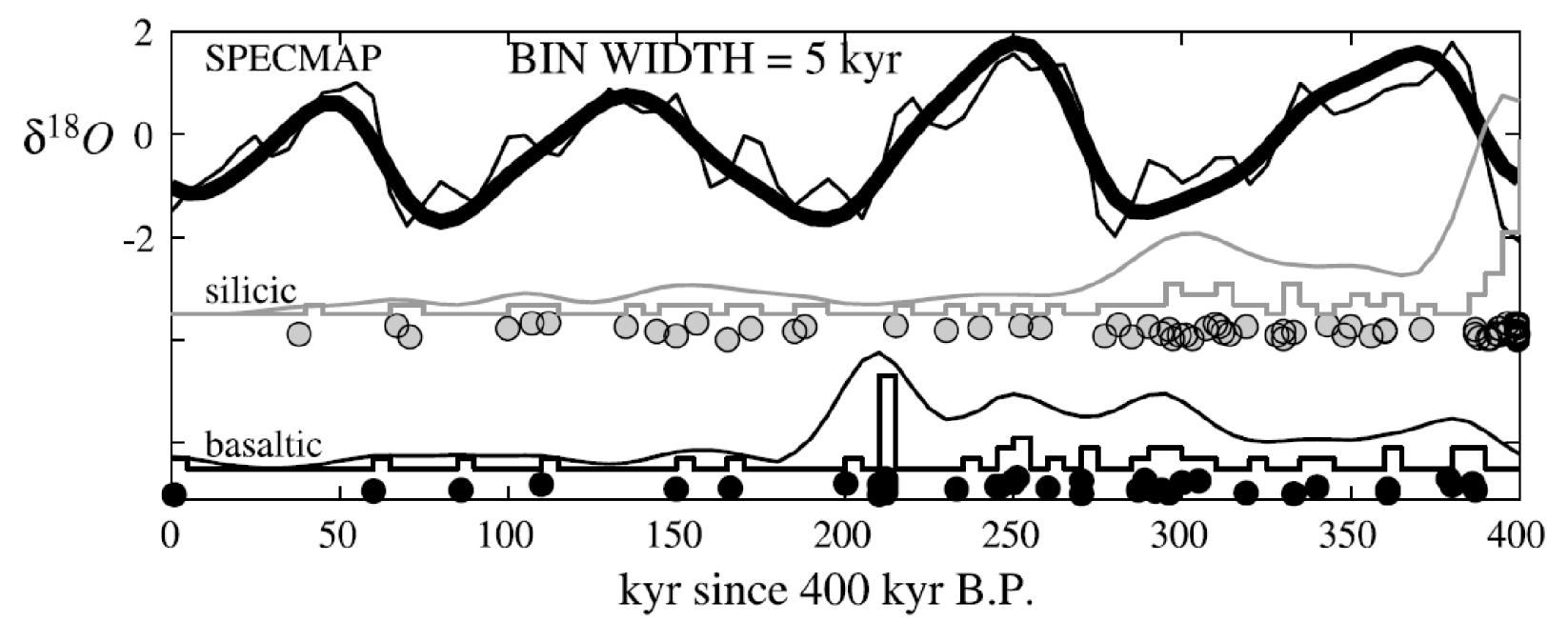

926

927

928

929

930 
$931 \quad$ Figure 7.

932

933

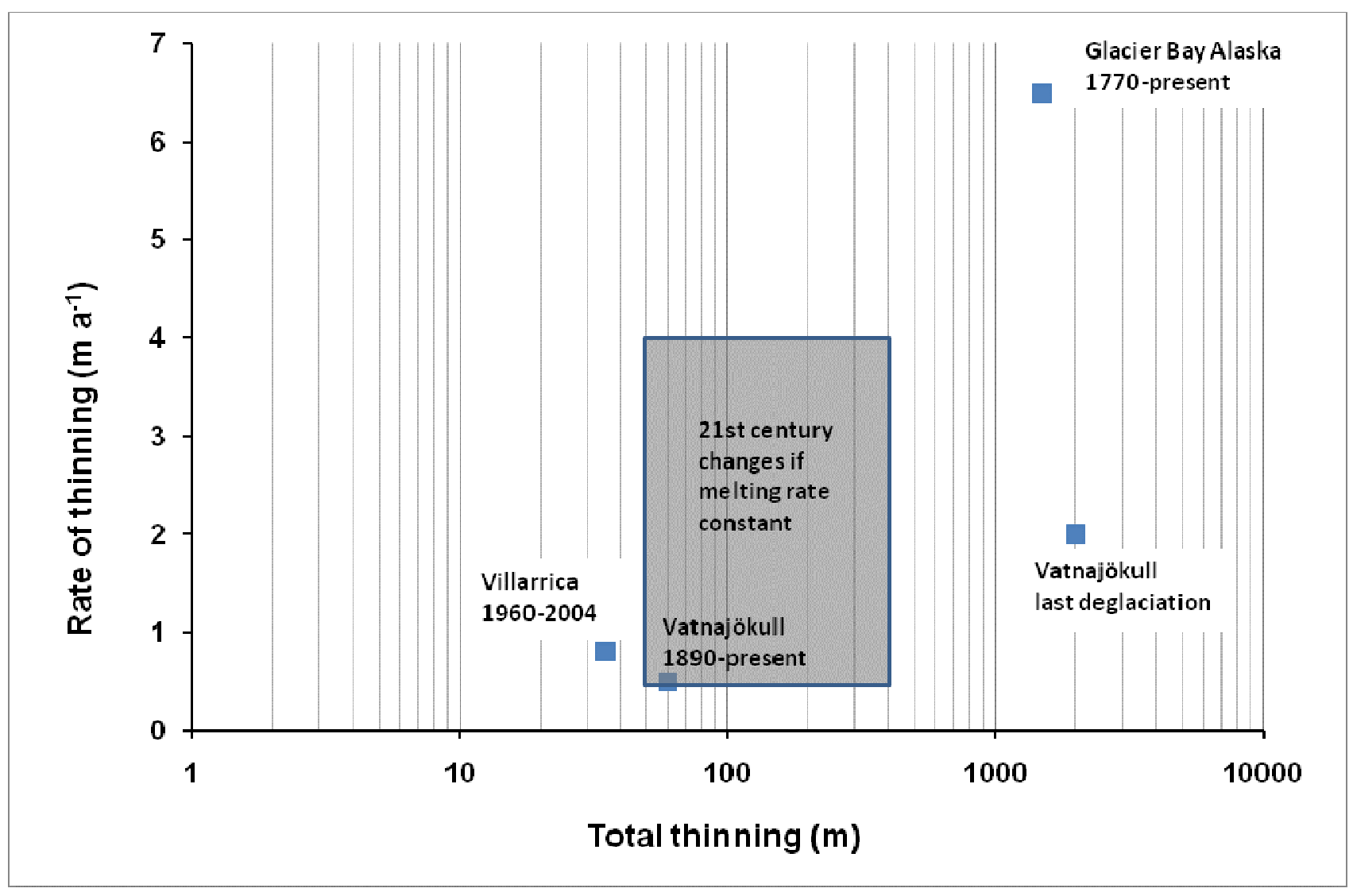

934 
$935 \quad$ Figure 8.

936

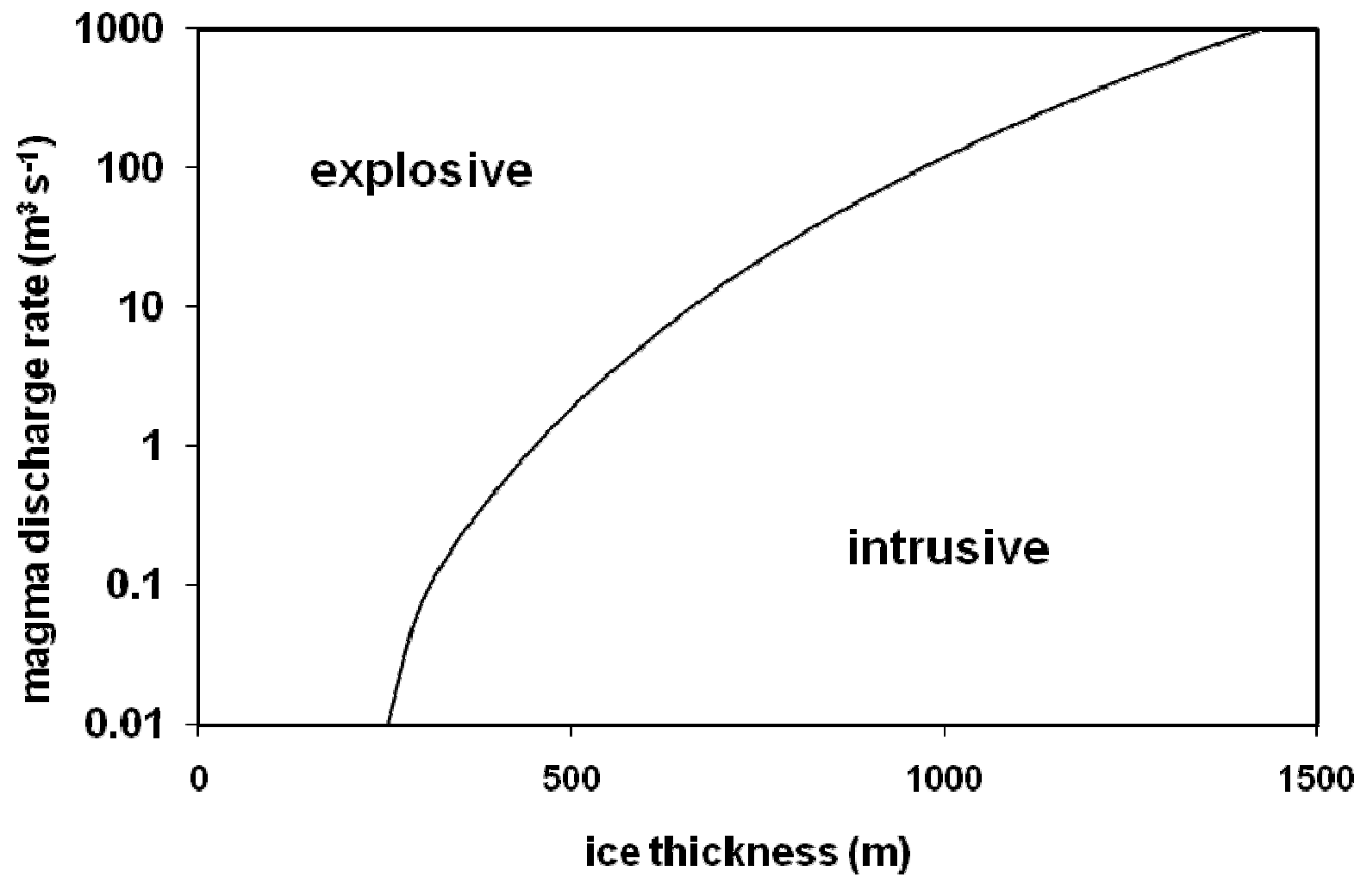

